\title{
Turning Waste into Beneficial Resource: Implication of Ageratum conyzoides L. in Sustainable Agriculture, Environment and Biopharma Sectors
}

\author{
Suman Paul ${ }^{1}\left[\right.$ - Badal K. Datta ${ }^{1}\left[\right.$ Milind B. Ratnaparkhe $^{2}\left(\mathbb{D} \cdot\right.$ Bhushan B. Dholakia $^{3}(\mathbb{C}$
}

Received: 27 March 2021 / Accepted: 21 September 2021 / Published online: 10 October 2021

(c) The Author(s), under exclusive licence to Springer Science+Business Media, LLC, part of Springer Nature 2021

\begin{abstract}
The annual herb, Ageratum conyzoides L. (Asteraceae), is distributed throughout the world. Although invasive, it can be very useful as a source of essential oils, pharmaceuticals, biopesticides, and bioenergy. However, very limited information exists on the molecular basis of its different utility as previous investigations were mainly focused on phytochemical/biological activity profiling. Here we have explored various properties of A. conyzoides that may offer environmental, ecological, agricultural, and health benefits. As this aromatic plant harbors many important secondary metabolites that may have various implications, biotechnological interventions such as genomics, metabolomics and tissue-culture can be indispensable tools for their mass-production. Further, A. conyzoides acts as a natural reservoir of begomoviruses affecting a wide range of plant species. As the mechanisms of disease spreading and crop infection are not fully clear, whole-genome sequencing and various advanced molecular technologies including RNAi, CRISPER/Cas9, multi-omics approaches, etc., may aid to decipher the molecular mechanism of such disease development and thus, can be useful in crop protection. Overall, improved knowledge of A. conyzoides is not only essential for developing sustainable weed control strategy but can also offer potential ways for biomedicinal, environment, safe and clean agriculture applications.
\end{abstract}

Keywords Ageratum conyzoides · Agri-biotechnology $\cdot$ Biopharma $\cdot$ Crop protection $\cdot$ Clean environment $\cdot$ Genome editing $\cdot$ Multi-omics $\cdot$ NGS $\cdot$ RNAi $\cdot$ Secondary metabolites

$\begin{array}{lll}\text { Abbreviations } & \text { GC-FID } \\ \text { 2,4-D } & \begin{array}{l}\text { 2,4-Dichlorophenoxyacetic } \\ \text { acid }\end{array} & \\ & \begin{array}{l}\text { Ageratum enation virus } \\ \text { Ageratum yellow leaf curl } \\ \text { betasatellite }\end{array} & \text { GC-MS } \\ \text { AYLCB } & \text { Ageratum yellow vein virus } & \text { GTI } \\ & \text { HPLC-Denzyl aminopurine } \\ \text { AYVV } & \begin{array}{l}\text { Completely randomized } \\ \text { BAP }\end{array} & \\ \text { CRD } & \text { HPLC-HRM }\end{array}$

Bhushan B. Dholakia

bhushan1410@yahoo.com

1 Department of Botany, Tripura University, Suryamaninagar, Tripura 799022, India

2 ICAR-Indian Institute of Soybean Research, Khandwa Road, Indore, Madhya Pradesh 452001, India

IAA

IBA

ISSR

LC-MS

MS

MYMIV

NAA
Gas chromatography equipped with flame ionization detector

Gas chromatography-mass spectrometry

Growth tolerance index

High-performance liquid chromatography with diode array detector

High-performance liquid chromatography-high-resolution mass spectrometry

Indole-3-acetic acid

Indole-3-butyric acid

Inter simple sequence repeats

Liquid chromatography-mass spectrometry

Murashige and Skoog

Mungbean yellow mosaic

India virus

$\alpha$-Naphthalene acetic acid 


\begin{tabular}{|c|c|}
\hline NGS & Next-generation sequencing \\
\hline NTSR & Non-targeted-site resistance \\
\hline PM & Point mutation \\
\hline qRT-PCR & $\begin{array}{l}\text { Qualitative real-time poly- } \\
\text { merase chain reaction }\end{array}$ \\
\hline RAPD & $\begin{array}{l}\text { Random amplified polymor- } \\
\text { phic DNA }\end{array}$ \\
\hline RFLP & $\begin{array}{l}\text { Restriction fragment length } \\
\text { polymorphisms }\end{array}$ \\
\hline SGS & Single-gene sequencing \\
\hline SSR & Simple sequence repeats \\
\hline TLC & Thin-layer chromatography \\
\hline TSR & Target-site resistance \\
\hline TYLCTZV & $\begin{array}{l}\text { Tomato yellow leaf curl } \\
\text { Tanzania virus }\end{array}$ \\
\hline UPLC-PDA-ESI-QToF-MS & $\begin{array}{l}\text { Ultra performance liquid } \\
\text { chromatography, coupled } \\
\text { to photodiode-array and } \\
\text { electrospray ionization/quad- } \\
\text { rupole-time-of-flight mass } \\
\text { spectrometry }\end{array}$ \\
\hline
\end{tabular}

\section{Introduction}

Ageratum conyzoides $\mathrm{L}$., an important medicinal herb from the Asteraceae family, is native to Central America but has been found globally including Africa, Asia, and South Pacific Islands [1]. The plant has different names as per the language such as Goat weed (English), Visadodi (Hindi), Visamustih (Sanskrit), Mejorana (Spanish), Mentrasto (Portuguese), Bhedaa Jhaar (Nepali), and Uralgidda (Kannada). The genus name Ageratum is based on the Greek word 'a geras' (means non-aging), while the species name Conyzoides is through 'konyz' (as it looks similar to the Inula helenium L.) [2]. The plant usually grows close to habitation and prospers best in soils with high nutrients, minerals, and moisture content [3]. It is very frequently found in and around waste places, gardens, grasslands, disturbed habitats, forest edges, watercourses, ruined sites, etc., covering from sea level to mountain. With a height of 1-2 $\mathrm{m}$, this aromatic herb shows annual, erect, branched, slender, and hairy features. White hairs are found on the leaves and stems. Leaves are simple with petiolate, ovate, or rhomboid-ovate shapes with a size range of $1-10 \mathrm{~cm} \times 0.5-7.0 \mathrm{~cm}$, apex acute, and length up to $7.5 \mathrm{~cm}[4,5]$. Generally, the flower color is white to purple with an inflorescence arrangement of a close terminal type. The achene-type fruits are effortlessly dispersed. The seeds having photoblastic nature may often lose within a year [6]. Although about 30 species have been reported from the Ageratum genus, the number of phytochemically characterized species is low. The essential oils obtained from A. conyzoides contain hydrogen cyanide and coumarin that may contribute to a powerful nauseating odor [7]. The plant has been mainly studied for its biological activities along with potential medicinal applications and earlier reviews have focused largely on pharmacological activities from $A$. conyzoides [4, 8-10]. However, the current study explores various ways of modern biotechnological interventions by which it can offer solutions for a better environment, ecology, health, and/ or agriculture. The demand is growing on crop breeding for improved resilience against abiotic and biotic stress with changing climatic conditions globally. Based on various biological and chemical properties, this weed plant might be potentially turned into a beneficial commodity while addressing important questions such as (1) how can we utilize it for the sustainable environment, agriculture, and also the industrial sector? (2) How it can be used in agricultural paste management? (3) How modern molecular and tissue-culture techniques can be applied for its mass multiplication and production of important secondary metabolites with potential utility in safeguarding agriculture, health, or the environment? (4) How can we exploit modern biotechnological tools to prevent the spread of disease from A. conyzoides and thus, can utilize this knowledge to generate resistant crops?

\section{The Usefulness of $A$. conyzoides in Agriculture, Environment, and Industrial Utilities}

Ageratum conyzoides successfully invades native habitats due to its fast growth rates, short life cycles, drought tolerance, allelopathy, greater competitive abilities, and higher reproductive potential [11]. Moreover, seed germination is the most important stage in the plant life cycle that contributes to its distribution. As per the surrounding environment, A. conyzoides has a wide range of temperature and light suitability to allow seed germination, which helps them to adapt to different local micro-habitats [12]. On the other side, the germination and growth rates of $A$. conyzoides were severely reduced in an experimental study by the application of different concentrations $(50,100$, and $200 \mathrm{M})$ of parthenin (a sesquiterpene lactone from Parthenium hysterophorus L.), while it was completely inhibited at $400 \mathrm{M}$ level [13]. The parthenin exhibited germination and growth reduction effects by altering the contents of various macromolecules (proteins, carbohydrates, chlorophyll, etc.) and specific activities of important enzymes such as protease, $\alpha$-amylase, and $\beta$-amylase.

Further, novel genetic resources with higher yield and capacity to withstand the invasive species during climate change scenarios can be developed based on the advanced knowledge from the genetic exploration on the causal physiological processes, which offer competitive advantages to 
weed plants [14]. For instance, a study revealed that the average number of plant species and diversity was reduced by $32.10 \%$ and $41.21 \%$, respectively, due to the weed invasion at Shivalik hills of Hamirpur district in Himachal Pradesh, India. A. conyzoides invasion significantly reduced the productivity and diversity of native species [5]. Moreover with a nutrient gradient, phenotypic plasticity, growth, and functional traits of A. conyzoides and Eupatorium catarium Veldkamp were analyzed under two contrasting conditions. The study revealed similar biomass of these two species under low-nutrient treatment with non-competitive condition. However, the addition of nutrients led to increased biomass in them. Consequently, under high-nutrient treatment, E. catarium and A. conyzoides had better growth over Vernonia cinerea (L.) Less. (a native species) in both competitive and non-competitive conditions [15]. On the other side, these two invasive species and the native plant exhibited similar growth during comparatively low nutrients in soil despite having sufficient water and light availability [16]. Thus, based on the surrounding environmental conditions $A$. conyzoides can potentially affect growth as well as plant diversity. Consequently, superior knowledge of various attributes of $A$. conyzoides is vital to develop better ways of weed control. It can potentially be useful as a source of essential oils, pharmaceuticals, biopesticides, and bioenergy with different applications (Fig. 1) [17]. Its allelochemicals are potential natural pesticides, which can offer a better solution for weed and pest management [16]. This plant otherwise can also be used as organic material to improve soil nutrient levels. The A. conyzoides was applied as Bokashi $(100,120,140,160 \mathrm{~g} /$ polybag in a test and control of $0.6 \mathrm{~g}$ NPK/ polybag) to determine their nutrient and growth effects on tomato. The Bokashi of Bandotan (A. conyzoides) $120 \mathrm{~g} /$ polybag exhibited the greatest effect on the tomato weights.

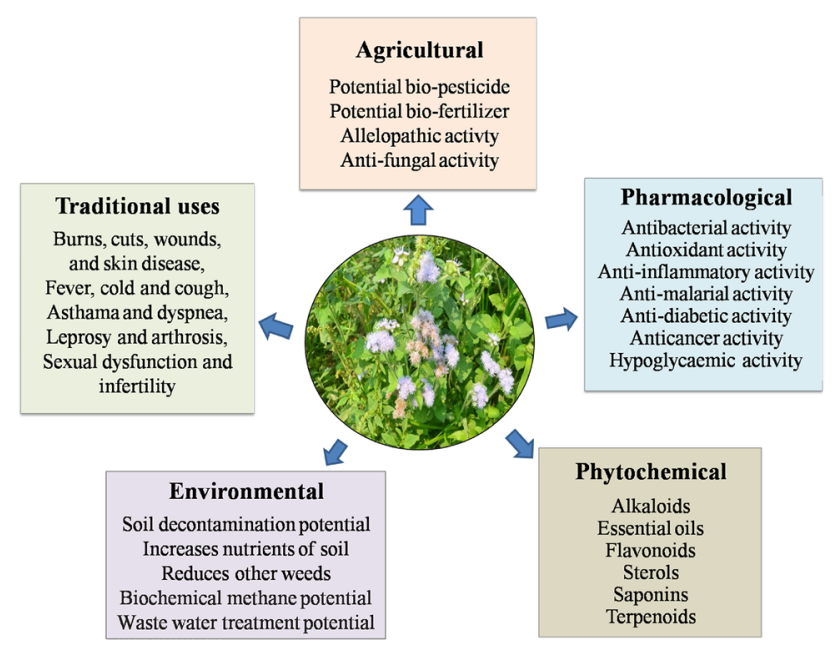

Fig. 1 Various important activities / applications of A. conyzoides
However, there were no effects on the biomass, height, wet weight, as well as nutrient contents (vitamin A and C) of tomato [19]. Extrinsic environmental variables (total soil nitrogen, and organic matter) and the evolutionary structure of the resident community significantly affected the diversity of A. conyzoides [20].

Phytopathogens (e.g., fungi, bacteria, viruses) cause various diseases to crops and lead to a decline in one-third of global agriculture production [21]. To mitigate this loss, different chemicals/ fertilizers (viz. fungicides, pesticides, etc.) are used which could have severe toxic effects on human beings as well as on surrounding environment [22]. Subsequently, synthetic and chemical fertilizers take a longer time to be degraded in soil compared to biofertilizers. Extracts of many plants including invasive species are known to exhibit allelopathic properties and can be utilized in agriculture as biofertilizers. The active ingredients found in these plants can be used in the form of extracts or can also be synthesized. Plant extracts can have a low environmental impact due to their fast degradation in soil [23]. For example, the suppressive effects of $A$. conyzoides were evaluated on the growth and germination response from radish (Raphanus sativus L.) and paddy weeds [Echinochloa crus-galli (L.) P. Beauv., Monochoria vaginalis (Burm.f.) C. Presl and Aeschynomene indica L.]. In comparison to A. conyzoides root and stem tissue, leaves ( $2 \mathrm{t} / \mathrm{ha}$ input) showed significant suppression with $\sim 70 \%$ growth reduction of E. crus-galli while completely prevented the germination of $M$. vaginalis and A. indica in calcareous soil conditions [24]. Similar treatment $(2 \mathrm{t} / \mathrm{ha})$ with leaves from $A$. conyzoides on a rice (Oryza sativa L. var. indica) field led to an $86 \%$ decrease in paddy weeds. This not only significantly lowered the fresh and dry weights ( $75 \%$ inhibition) of these weeds but also contributed to a $14 \%$ higher rice yield in comparison to the butachlor application [24]. On the other side, A. conyzoides extract (ACE) was found to reduce the growth (e.g., plant height, number of branches and leaves) and development of redroot amaranth (Amaranthus retroflexus L.), peanut (Arachis hypogaea L.), cucumber (Cucumis sativus L.), ryegrass (Lolium multiflorum Lam.), and rice (Oryza sativa L.) by releasing water-soluble phytochemicals (e.g., precocenes, 2H-benzopyran, monoterpenes, and sesquiterpenes) [25, 26]. Apart from this, A. conyzoides leaf biomass was found to increase the microbial enzymatic activities, waste mineralization and microbial population build-up, earthworm growth, and fecundity when applied to a vermicomposting bed at $50-75 \%$ proportion along with cow dung. Compost extracts enhanced the soil respiration rate and the germination index of mustard (Brassica campestris L.), indicating the suitability of $A$. conyzoides as a potting media for vermicomposting [27]. Thus, A. conyzoides might be considered as a promising natural growth promoter, herbicide 
and can offer valuable solutions for sustainable and safe agriculture.

\section{For a Clean Environment}

Increasing population density and climate change along with inefficient management of water resources have led to water scarcity all over the globe, and the need of the hour is to develop an efficient water harvesting system utilizing solar energy and re-using wastewater [28]. The wastewater is widely used in agricultural fields in peri-urban areas of developing countries [29]. However, the wastewater used in agriculture for irrigating crops contains harmful pathogens, bacteria, viruses, excessive nitrogen, phosphorus, and heavy metals, which are also deleterious to humans and animals [30]. Wastewater treatment plants used in urban areas are very costly and often yield partially treated wastewater that may have still some contaminants [31]. To overcome this, constructed wetlands that mimic the functions of natural wetlands can be used to treat wastewater naturally involving wetland vegetation and associated microbial populations that can uptake excessive nitrogen, phosphorus, and heavy metals [32]. Several wetland plants such as Typha latifolia L., T. angustifolia L., Schoenoplectus validus (Vahl) Á. Löve \& D. Löve, Phragmites australis (Cav.) Trin. ex Steud., Juncus effusus L., Canna indica L., Eichhornia crassipes (Mart.) Solms, and Lemna minor L. have the potential to remove contamination of nitrogen and phosphorus from wastewater [33, 34]. More recently, A. conyzoides has indicated similar efficacy in combination with wetland plants. The study has demonstrated effective removal of excessive phosphorus, nitrogen, and fecal coliforms from domestic wastewater using A. conyzoides along with Pistia stratiotes L., T. latifolia, and $C$. indica [35]. Additionally, municipal and electronic wastes can lead to more soil pollution, which is a grave universal issue for waste sites and related environments [36]. The phytoremediation approach can offer a potential strategy to protect the soil environment from such contamination [37, 38]. As A. conyzoides can grow easily on contaminated soil, it can take up heavy metals from any waste site [36]. Soil decontamination potentiality of A. conyzoides was evaluated in pot experiments using ethylenediaminetetraacetic acid (EDTA at $0.1 \mathrm{~g} / \mathrm{kg}$ ) in combination with kinetin $(100 \mu \mathrm{M})$. Leaves exhibited the highest accumulation of $\mathrm{Fe}(6.51-38.58 \%), \mathrm{Mn}(0.14-73.12 \%), \mathrm{Zn}$ (5.24-269.07\%), and $\mathrm{Cu}(9.38-116.59 \%)$, whereas accumulation of $\mathrm{Pb}(22.83-113.41 \%)$ and $\mathrm{Cr}(21.05-500 \%)$ was highest in the stem, as compared with controls. Plants exhibited overall improved growth with the planned kinetin-EDTA combination [36]. Similarly, another weed
Santa-Maria (P. hysterophorus L.) can also reduce heavy metals from contaminated soil [39].

\section{For Industrial Purpose}

The A. conyzoides extract (ACE) can be used to manufacture better sodium alginate (SA) films having improved physical, mechanical, and thermal assets [40]. With ACE, the tensile strength was superior and the water vapor transmission rate was significantly reduced in SA film. Consequently, the thermal stability and swelling rate of the SA film were also better. Thus, ACE-SA film can potentially serve as an effective wound-dressing material [40]. Additionally, the biochemical methane potential (BMP) of A. conyzoides has been studied to find the ideal food to microorganism (F/M) ratio and as an alternative energy source [41]. The assay revealed that out of different ratios examined (1.0, 1.5, 2.0, and 2.5), the F/M ratio of 2 showed maximum methane $\left(\mathrm{CH}_{4}\right)$ and volatile solid (VS) production from the anaerobic digestion. Further, the highest biogas production was achieved with $205 \pm 10 \mathrm{~mL} \mathrm{CH}_{4} / \mathrm{g}$ VS and cumulative methane production reached up to $4994 \pm 25 \mathrm{~mL}$ on the $25^{\text {th }}$ day. Within 30 days of incubation, $80 \%$ of biogas production was achieved and kinetic study also confirmed the efficiency of biogas production [41]. Thus, the biomass from this terrestrial invasive plant can be converted as a very effective resource and used in an eco-friendly manner with the generation of viable clean energy at a minimum cost.

\section{Effectiveness of Secondary Metabolites from $A$. conyzoides}

The chemical composition of $A$. conyzoides has been analyzed by various qualitative and quantitative methods such as gas-chromatography-mass spectrometry (GC-MS), GCequipped with flame ionization detector (GC-FID), liquidchromatography-mass spectrometry (LC-MS), thin-layer chromatography (TLC), high-performance liquid chromatography-high-resolution mass spectrometry (HPLCHRMS), HPLC with diode array detector (HPLC-DAD), and ultra-performance liquid chromatography, coupled to photodiode-array and electrospray ionization/quadrupoletime-of-flight mass spectrometry (UPLC-PDA-ESI-QToFMS). These have allowed the identification of various phytochemicals, such as the pyrrolizidine alkaloids, saponins, coumarin, pyrrolone, phenolic acids, polymethoxyflavones, and terpenoids [8, 42-44]. A. conyzoides contains many different types of sterols like brassicasterol, $\beta$-sitosterol, cholesterol, stigmasterol, spinasterol, etc. [45, 46]. Similarly, it is also very rich in flavonoids such as scutellarein-5,6,7,1tetrahydroxyflavone, polymethoxy flavones, eupalestin, quercetin, kaempferol, kaempferol 3,7-diglucopyranoside, 
(2S)-7, 3', 4'-trimethoxyflavone, (2S)-7-methoxy-3', 4'methylenedioxyflavan, 5,6,7,3',4',5'-hexamethoxyflavone, nobiletin, and 5'-methoxynobiletin [43, 47, 48]. Earlier from the stems, a new isoflavone glycoside, $\left[5,7,2^{\prime}, 4^{\prime}-\right.$ tetrahydroxy-6,3'-di-(3,3-dimethylallyl)-isoflavone-5-O$\alpha$-L-rhamnopyranosyl- $(1 \rightarrow 4)-\alpha$-Lrhamnopyranoside] was detected [49]. Glycosidal flavonoids isolated from ethyl extracts are $p$-hydroxybenzoic acid, quercetin-3-Orhamnopyranoside, and quercetin-3,7-diglucopyranoside [24, 50, 51]. Additionally, GC-MS analysis of A. conyzoides essential oils are reported to contain 7-methoxy-2,2-dimethylchromene (precocene I), $\beta$-copaene, hexanal, transcadina-1(6), ageratochromene (precocene II), $\alpha$-calacorene, caryophylla-4(12), germacrene-D, trans-cadina-1(6),4-diene, $8(13)$-diene-5- $\beta$-ol, $\beta$-caryophyllene, $\alpha$-caryophyllene, trans$\beta$-farnesene, $\beta$-cubebene, coumarin, phytol (a diterpene alcohol) and 1,10-di-epi-cubenol [52-54]. Additionally, a total of 51 constituents including chromenes (85.2\%), chromans $(0.9 \%)$, oxygenated monoterpenoids $(1.4 \%)$, phenylpropanoids and benzenoids (2.33\%), oxygenated sesquiterpenoids $(0.8 \%)$, monoterpenoid hydrocarbons $(5.0 \%)$, and sesquiterpenoid hydrocarbons $(4.3 \%)$ have been reported from the leaves of $A$. conyzoides [55]. Similarly, A new chromene, [2,2-dimethylchromene-7-methoxy-6-O- $\beta$-Dglucopyranoside], has also been identified from the total plant ethanol extract [56].

Many of these compounds can be useful in different ways (Fig. 2) such as a substitute for synthetic and chemical fungicides [57, 58]. Soil pathogenic fungi and weed invasion are major threats to citrus plants as they significantly reduce

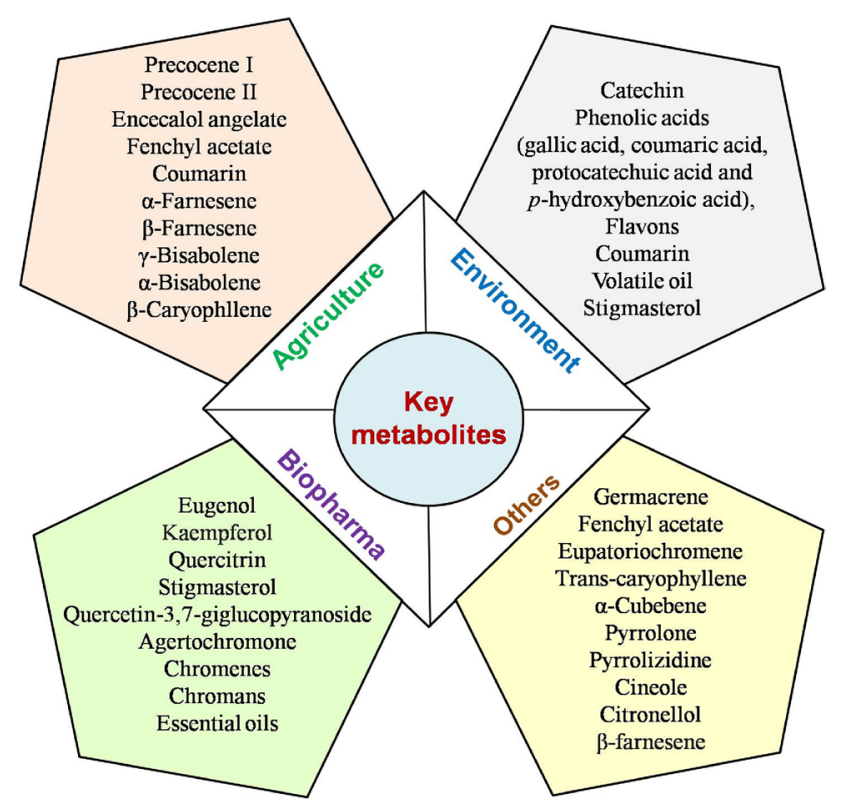

Fig. 2 Potential metabolites from A. conyzoides having implication in different areas the yield. The invasion of other weeds and pastes can be controlled by incorporating $A$. conyzoides plants in the citrus orchards [59]. Three flavones and ageratochromene allelochemicals (levels of 11 to $93 \mu \mathrm{g} / \mathrm{g}$ of soil) were released from A. conyzoides on citrus orchards that significantly inhibited (47.3\% to $71.2 \%)$ the development of three weeds (Cyperus difformis L., Bidens pilosa L., and Digitaria sanguinalis (L.) Scop.). This also prevented the growth of disease-causing soil fungi, namely Fusarium solani Mart. (Sacc.), Pythium aphanidermatum (Edson) Fitzpatrick and Phytophthora citrophthora (R.E. Sm. \& E.H. Sm.). This finding has suggested that the incorporation of $A$. conyzoides and isolated allelochemicals (flavones and ageratochromene) in soil may be useful in controlling other invasive weeds and phytopathogens [59]. Similarly, the aqueous, $n$-hexane and methanol extracts from various tissues of $A$. conyzoides at different concentrations $(2,4$, and $6 \mathrm{w} / \mathrm{v})$ were used to assess the antifungal potential against pathogenic fungi Fusarium solani. All the extracts exerted antifungal activity and significantly repressed the growth of the fungi [60]. Another such study has been recently performed on Puccinia arachidis Speg., which is the causal organism of rust disease in peanuts. Crude ACE was very effective against this pathogen when used at $2.5 \%$ to $5.0 \%$ concentrations. Additionally, the aqueous ACE showed maximum antifungal activity against Aspergillus niger Tiegh. and A. ustus (Bainier) Thom \& Church with an average inhibition zone of $20 \mathrm{~mm}$, while the minimum inhibition was recorded against $A$. fumigatus Fresen. with $7 \mathrm{~mm}$ at $800 \mathrm{mg} / \mathrm{mL}$ concentration [57]. This indicates that it can also be an effective biofungicide and thus, helps to reduce the use of synthetic fungicides [58]. Taken together, A. conyzoides is very rich in different compounds such as sterols, flavonoids, saponins, chromenes, pyrrolizidine, alkaloids, coumarin, pyrrolone, terpenoids, and lignin, and thus, can have potential implications in different sectors for a safe environment, agriculture, and biomedicine (Fig. 2).

Essential oils from A. conyzoides can also be a good botanical insecticide and may be useful against insects for integrated pest management practices. These secondary metabolites such as alkaloids, flavonoids, phenols, and tannins possibly can be exploited for the development of natural pesticides and controlling pests for sustainable crop production [18]. For instance, using these oils, in vitro and in vivo fumigant tests resulted in $100 \%$ mortality of Tribolium castaneum (Herbst), the storage grain insect. A. conyzoides essential oils totally destroyed the insects at $1000 \mathrm{ppm}$. On the other side, these oils were non-phytotoxic; and did not affect the seed germination and growth of the seedlings [61]. Similarly, different concentrations $(0.1,0.2,0.5$, and $1.0 \%)$ of petroleum ether leaf extract were used to evaluate insecticidal activity against the Epilachna 28 punctata larvae. The $1.0 \%$ and $0.5 \%$ of leaf ACE exhibited $100 \%$ and $66.67 \%$ 
mortality of the larvae, respectively. Both $0.1 \%$ and $0.2 \%$ concentration indicated $33.33 \%$ mortality [62]. Additionally, the whole plant ACE when used in different doses (2, $4,6,8$, and $10 \%$ conc.) to assess the potential as a biopesticide against pest of Caisim (Brassica juncea L. Czern.), 4\% level was the most effective botanical pesticide to control an amount of pest in Caisim compared to the treatment without pesticides [63]. In another recent study, methanolic leaf $\operatorname{ACE}(0,6,8,10$, and $12 \%$ conc.) was used as a biopesticide against caterpillar larvae (Spodoptera litura Fabricius). Larvae mortality rate was significantly improved with the increased ACE concentration with the highest mortality at the $12 \%$ level [64]. Antifungal bioassays using various fractions of stem ACE such as $n$-hexane, chloroform, $n$-butanol, and ethyl acetate were used against disease-causing pathogen Macrophomina phaseolina (Tassi) Goid. All fractions exhibited a reduction in pathogen biomass over the control. Several compounds from ACE [such as 2H-1-benzopyran, 7-dimethoxy-2,2-dimethyl, hexadecanoic acid, 11-octadecenoic acid, methyl ester, 1,2-benzenedicarboxylic acid, and mono(2-ethylhexyl) ester] could exert biopesticide potential [65]. However, these isolated compounds should be further evaluated separately for their potential application in agriculture as a biopesticide. Taken together with these reports, Roiba and Stevenson [66] have strongly recommended $A$. conyzoides as a potential biopesticide, which is very beneficial on insects including ladybirds, spiders, and hoverflies.

Further, allelochemicals can restrain growth of other weeds; however, they are not much effective to themselves or the weeds from the same families. The allelopathic activity was evaluated in Sesamum indicum L. using aqueous ACE at different concentrations $(5,10,15$, and $20 \%)$. The ACE was inhibitory to seed germination, shoot and root development of sesame plants. There was an increase in allelopathic effect with a gradual increase in ACE concentrations [67]. Similarly, the aqueous acetone shoot ACE at different concentrations $\left(0,0.1,0.3,1.0,3.0\right.$, and $\left.10.0 \mathrm{mg} / \mathrm{cm}^{3}\right)$ resulted in allelopathic activity and inhibited the seed germination, shoot and root growth of Amaranthus caudatus L., Lactuca sativa L. and Digitaria sanguinalis (L.) Scop. [68]. Overall, these investigations have potentially indicated that such chemicals of $A$. conyzoides can be effectively utilized for various purposes.

\section{Evaluation of Traditional Medicinal Uses by Molecular Tools}

Plants provide many different types of products. From the days of ancient civilizations, plants are widely used as raw materials in different types of medicine [69]. This knowledge of traditional remedies is extensively utilized for new drug development by the contemporary industry [70]. Many sophisticated biotechnological interventions viz., tissue-culture, marker-assisted breeding, DNA microarrays, metabolomics, proteomics, functional genomics, bioanalytics, etc., are used nowadays in novel drug discovery and formulations from ethnomedicinal plants [71]. A. conyzoides has been traditionally used as a medicine by local indigenous people from the majority of globe to cure various diseases/ ailments (Table 1). The plant is utilized to cure dyspnea, skin diseases, ulcer, wound, etc., and also as a purgative, and febrifuge. In some African countries, the plant is useful in conventional medicine due to its anti-asthmatic, antispasmodic, and hemostatic properties [72, 73]. The ACE contains numerous phytochemical compounds that may have different therapeutic activities such as antioxidant, antibacterial, antimicrobial, anticancer, etc., either from crude or tissue-specific fractions (Table 2) [8, 9, 74]. It has been also used to cure urinary and prostate-related issues in traditional practices for a long time. However, there is a deficit of gene expression studies and evaluation of the pharmacological activity of $A$. conyzoides using advanced molecular tools. Pharmaceutical treatments of prostate swelling (Benign prostate hypertrophy- BPH) include the use of 5 - $\alpha$-reductase inhibitors, which loosen up the muscles in the region of the urethra and bladder to mitigate urine retention. The effect of ACE on the gene expression of 5- $\alpha$-reductase was assessed for efficacy and safety in treating BPH. The extract showed a significantly reduced human 5 - $\alpha$-reductase mRNA level in prostate epithelial cells. Thus, A. conyzoides could potentially be used for the treatment of BPH by decreasing the enzyme activity of 5- $\alpha$-reductase [74], and can be employed after purifying the active component from ACE with subsequent clinical studies.

Progress in bioinformatics has enormously facilitated the identification of target drug molecules and their interactions using computational algorithms before they can be used for further experiments. In silico analysis not only helps to screen and design potential drug targets for various diseases using isolated phytochemicals but also to identify and predict the metabolic fate of such compounds. Phytochemicals isolated from ACE have been virtually screened using in silico studies for their potential application in biopharma. Several compounds viz. precocene I, $\beta$-sitosterol, precocene II, 6-vinyl-7-methoxy-2,2-dimethyl chromene (VMDC), stigmasterol, polymethoxyflavone, pyrrolizidine, neophytadiene, phytol, and caryophyllene isolated from ACE have been used to screen their potential application against various drug targets (e.g., MMP-9, p53, cox-2, $\alpha$-amylase, etc.) for various diseases like malaria, diabetes, breast cancer and cervical cancer [75-78]. Recently, key secondary metabolites (e.g., Kaempferol, Quercetin, etc.) isolated from ACE have shown potential as drug candidates against the SARS$\mathrm{CoV}-2$ virus. In silico molecular docking analysis has indicated that these metabolites may inhibit the replication of the 
virus by interacting with the active site residues of the main protease enzymes [79]. Thus, virtual screening and molecular dynamic simulations can be crucial tools to design and identify target drug candidates against various diseases in the future.

Numerous pro- and anti-inflammatory mediators are produced during the inflammatory process. From the leaves of A. conyzoides, eupalestin, 5'-methoxy nobiletin (MeONOB), and 1, 2-benzopyrone were isolated and evaluated for antiinflammatory effects. Various cytokines, genes, and enzymes involved in inflammation response were also analyzed [79, 80]. Isolated compounds and other fractions of ACE significantly reduced $(p<0.05)$ the levels of myeloperoxidase, nitric oxide, adenosine deaminase, leukocyte influx, etc., and also reduced the p-p38 MAPK and p-p65 NF-kB levels. The isolated compounds might have prevented the activation of MAPK and NF- $\mathrm{KB}$; and thus, attributing to the anti-inflammatory response of $A$. conyzoides [80]. Restricted movement with pain in joints due to inflammation is the main feature of Osteoarthritis (OA) [81]. The effect of leaf ACE on the OA has been studied in rats that might suggest how TNF- $\alpha$ and MMP-9 affect the proteoglycan swelling and degradation during the OA. The leaf ACE (at $160 \mathrm{mg} / 200 \mathrm{~g}$ body weight) significantly lowered the MMP-9 and TNF- $\alpha$ level. This suggested that ACE can reduce cartilage inflammation and degradation by potentially inhibiting the activities of TNF- $\alpha$ and MMP-9, respectively [82]. Also, the level of MMP-9 expression is the key indicator of triple-negative breast cancer disease diagnosis. Recently, Hariono et al. [78] used the $n$-hexane fraction of ACE to assess its inhibitory potential against MMP-9. The compound oxytetracycline (OTC) isolated from $n$-hexane fraction had a potent inhibitory effect against MMP-9 with $\mathrm{IC}_{50}$ value of $246.1 \mu \mathrm{g} / \mathrm{mL}$. Further, molecular docking analysis suggested that OTC inhibited MMP-9 activity by binding to the PEX9 domain rather than the catalytic site. Therefore, due to higher selective inhibition of MMP-9, OTC can be a safe and promising candidate against triple-negative breast cancer [78]. With the tremendous progress in advanced molecular technologies, more focused studies in the future would bring out numerous beneficial uses affirming biomedicinal properties of A. conyzoides.

\section{Tissue-Culture and Secondary Metabolite Production from $A$. conyzoides}

Although the Indian subcontinent contains the richest source of ethnomedicinally important plant species with approximately 45,000 plants, many of these resources are rapidly turning extinct [83, 84]. Medicinal and aromatic plants (MAPs) can produce a diverse array of secondary metabolites generating an invaluable resource of plant-derived bioactive compounds [85]. These are mainly represented as phenolics, nitrogen-containing compounds, terpenes, and terpenoids [86]. Such secondary metabolites from MAPs are widely utilized as a natural cure for various diseases. However, for large-scale production and proper exploration of medicinal properties with contributory secondary metabolites as well as conservation of MAPs, standard cell, organ, and tissue-culture protocols are required. Plant cell, tissue, and organ cultures offer an efficient homogeneous, controlled production of secondary metabolites, especially to meet commercial demands. These techniques have facilitated the identification and de novo synthesis of novel compounds in higher amounts than the intact natural plants [87, 88]. Tissue-culture techniques especially micropropagation can be a promising tool for the mass multiplication, secondary metabolites production, and conservation of these medicinally important plants $[89,90]$. However, very scanty information exists on the tissue-culture-related efforts on $A$. conyzoides. Earlier, a micropropagation protocol was developed from nodal explants of A. conyzoides [91]. Using different combinations of auxin and cytokinins in Murashige and Skoog (MS) medium the multiple shoot induction was achieved. A maximum no. of shoots/ explants was observed with a combination of indole-3-acetic acid (IAA) $(3.0 \mathrm{mg} / \mathrm{L})$ and 6-benzyl aminopurine (BAP) in MS medium. The elongation of multiple shoots was observed with $3.05 \mathrm{mg} / \mathrm{L}$ of BAP and IAA along with $600 \mathrm{mg} / \mathrm{L}$ activated charcoal containing MS medium. Out of different auxin-cytokinin combinations, IAA-BAP combinations at 2.0 and $3.0 \mathrm{mg} / \mathrm{L}$ concentrations exhibited the greatest induction of multiple shoots and roots, respectively. Similarly, Renu and Nidhi [92] also developed in vitro tissue-culture protocol using various mature plant parts of Adhatoda vasica Nees and A. conyzoides to explore and analyze the sterol content as they are extensively used in traditional medicine. $\beta$-sitosterol is the active phytosterol constituent present in the root, stems, and leaves of both of these plants. In A. vasica, callus culture from nodal explants was developed on MS medium containing BAP and $\alpha$-naphthalene acetic acid (NAA) at $0.5 \mathrm{mg} / \mathrm{L}$ and $2.5 \mathrm{mg} / \mathrm{L}$, respectively, whereas for $A$. conyzoides, stock callus was developed from nodal segments on MS medium with 2, 4-Dichlorophenoxyacetic acid (2, 4-D) and $\mathrm{BAP}$ at $3.0 \mathrm{mg} / \mathrm{L}$ and $0.5 \mathrm{mg} / \mathrm{L}$ concentrations, respectively. The callus culture was maintained for 18 months by frequent sub-culturing and analyzed for sterol contents. TLC and infrared (IR) spectroscopy confirmed the stigmasterol and $\beta$-sitosterol presence in different plant parts of both species. The six-week-old tissue of $A$. vasica exhibited higher concentrations of total sterol $[0.439 \mathrm{mg} / \mathrm{gram}$ dry weight (g d.wt.)], $\beta$-sitosterol $(0.272 \mathrm{mg} / \mathrm{g}$ d.wt.) and stigmasterol $(0.167 \mathrm{mg} / \mathrm{g}$ d.wt.) compared to $A$. conyzoides tissue (total sterol- $0.432, \beta$-sitosterol -0.270 and stigmasterol— $0.162 \mathrm{mg} / \mathrm{g}$ d.wt., respectively). In vivo studies 
of different tissues also revealed that $A$. vasica contained slightly higher levels of steroids compared to A. conyzoides [92]. In another separate investigation, nodal, leaf, and shoot-tip explants of $A$. conyzoides were utilized for in vitro culture protocol on MS medium having different 2, 4-D, and NAA levels [93]. The leaf explants exhibited the highest (86\%) frequency of callus induction when fortified with NAA (at $2.0 \mathrm{mg} / \mathrm{L}$ ) and 2, 4-D (2.5 mg/L). The auxiliary meristem ( $67 \%$ of explants) produced shoots $(2.70 \pm 1.05$ shoots per explants) when placed on MS medium containing $1.0 \mathrm{mg} / \mathrm{L}$ BAP and $0.5 \mathrm{mg} / \mathrm{L}$ NAA. Rooting of explants was accomplished with NAA $(2.5 \mathrm{mg} / \mathrm{L})$ and indole-3-butyric acid (IBA at $3.0 \mathrm{mg} / \mathrm{L}$ ). About $86 \%$ of nodal explants produced shoots when placed on MS medium containing NAA $(1.0 \mathrm{mg} / \mathrm{L})$ and BAP $(1.5 \mathrm{mg} / \mathrm{L})$ with $2.16 \pm 0.75$ shoots per explants. Similarly, MS medium having IBA $(3.0 \mathrm{mg} / \mathrm{L})$ and NAA $(2.5 \mathrm{mg} / \mathrm{L})$ were used in rooting of explants and this led to $86 \%$ response with $6.5 \pm 1.04$ roots per explants. These were then shifted to small cups filled with sand, vermiculite, and soil (1:1:1 combination) for hardening and later transferred to soil successfully for acclimatization. Additionally, endophytes are a promising source of biologically active compounds having potential applications in the medical, agricultural, and industrial sectors [94]. Endophytic microbes form a symbiotic association with their plant partners. They help plants to absorb nutrients efficiently and also provide protection against biotic and abiotic stresses. There are some reports indicating the presence of endophytes on A. conyzoides plants with several endophytic bacteria [94, 95] and fungi [96] that exhibit plant growth-promoting (PGPR) [94] as well as pharmacological activities [95, 97] by producing some important secondary metabolites (e.g., xanthorrhizol, orsellinic acid, $p$-hydroxybenzoic acid, scalarolide, 2-amino-3-quinoline carbonitrile and boric acid and stigmasterol). Overall, tissue-culture protocols can facilitate mass propagation and in vitro germplasm conservation of $A$. conyzoides as well as secondary metabolite production for various utilities [93].

\section{Role of Advanced Molecular Technologies for Better Utility of $A$. conyzoides}

In the last few decades, PCR-based tools and other advanced molecular technologies have been effectively used to forecast disease epidemiology as well as for the early detection and characterization of various disease-causing pathogens at different stages of crop development. Begomoviruses have become devastating pathogens for diverse crops due to intensive farming and transportation of plant material globally, as well as recombination and pseudo-recombination (reassortment of genetic materials) of viruses [98]. Several begomoviruses, namely ageratum yellow vein virus (AYVV), ageratum enation virus, tomato yellow leaf curl Tanzania virus, etc., reside naturally on $A$. conyzoides $[99,100]$. The viral proteins collectively capture the host cellular processes hampering/stifling the plant defense cascade. This leads to disease development by inducing programmed cell death and altering host metabolite biosynthesis with leaf enation, crumpling, yellowing, and stunting symptoms in plants [101, 102]. Additionally in opium poppy (Papaver somniferum L.), leaf curling with vein thickening was reported through ageratum leaf curl betasatellite and ageratum enation virus. The qRT-PCR analysis from the infected poppy samples suggested significant gene expression variations in the alkaloid pathway. As a result, the content of several key alkaloids such as codeine, morphine, papaverine, etc., was decreased, while the noscapine level was enhanced in the infected plants. Overall, such metabolite variations might lower the market worth of the poppy and other plants [101]. Consequently, begomoviruses infecting crops and other non-crop species can be detected efficiently by circomics (based on rolling circle amplification (RCA), RFLP, and pyro-sequencing combination) [103]. Circomics is a proficient and economic technique to detect geminiviral genomic components including their satellites without any a priori knowledge of their nucleotide sequences [104]. The genomic DNA and target gene sequences from the virus can be utilized effectively for developing virus-resistant crop varieties. Pathogens alter the host plant's defense mechanism and release cell wall degrading enzymes leading to successful disease development [105]. Some viruses also reported hijacking host RNA interference (RNAi) defense pathway that helps to increase their virulence while suppressing and silencing the host genes [106]. Additionally, whitefly (Bemisia tabaci Genn.) is a carrier of these begomoviruses that can affect diverse plant species such as crops, weeds, medicinal and aromatic plants $[107,108]$. Globally, the whitefly is a serious threat to many important plants due to the high invasiveness of the pest $[109,110]$. This pest damages plants in multiple manners, such as (1) by direct infection, (2) by honeydew secretion to attract fungi on the infected sites, and (3) via begomoviruses $[111,112]$. Begomoviruses are infecting various plants worldwide due to increased levels of biotypes B and Q of $B$. tabaci $[110,111]$. In addition to this, the $\mathrm{Q}$ biotype is highly defiant to most insecticides (e.g., pyriproxyfen and neonicotinoid), thus making it difficult to globally manage $B$. tabaci and begomoviruses [113]. For example, normal tomatoes can have begomoviruses (AYVV) natural transmission from the infected $A$. conyzoides via whitefly (B. tabaci B biotype) on the Ishigaki Island [114] resulting in severe yellowing and curling of tomato leaves (Fig. 3A). As a protection strategy through the utilization of viral genome sequences, $A$. conyzoides can be engineered with antimicrobial peptides or compounds [115] to directly suppress the virus infection (Fig. 3B). Alternatively, the vector- whitefly can also 


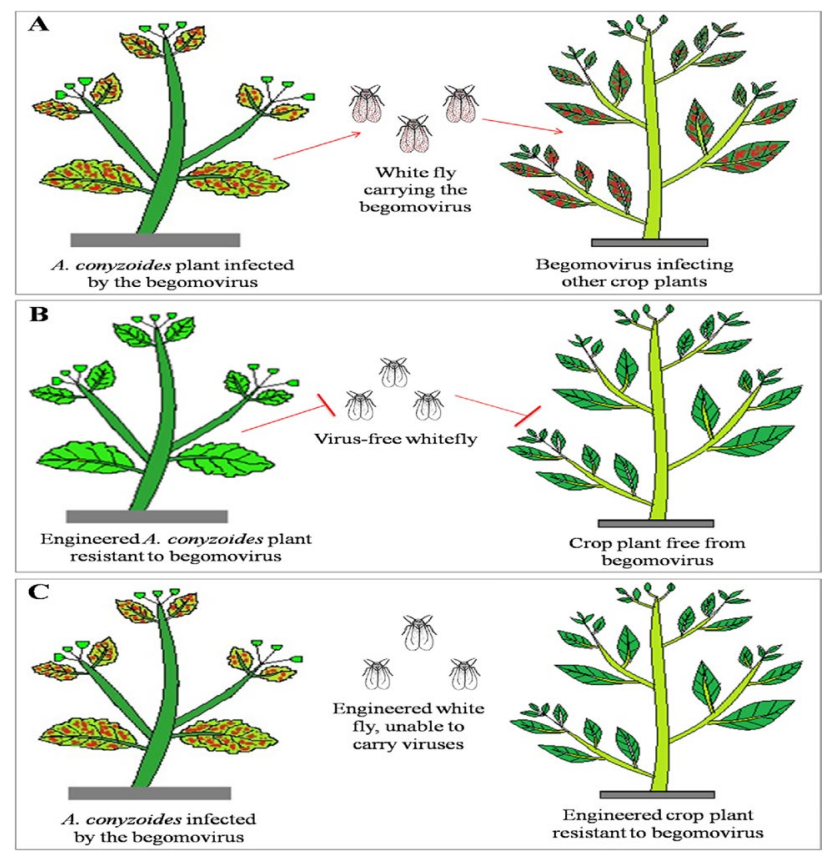

Fig. 3 Transmission of begomovirus from A. conyzoides to other crop plants and potential ways to reduce such infection. A Begomovirus gets transmitted through whitefly from host to other crops, B engineered $A$. conyzoides plant is resistant to begomovirus infection and thereby begomovirus transmission is blocked, $\mathbf{C}$ engineered crop plant with resistance against begomovirus or engineered whitefly with inability to carry pathogen (virus-free) can offer valuable protection to nearby plants and thus, can minimize the damage from begomovirus

be targeted by advanced genetic engineering tools to make them incapable of carrying these pathogens, and thereby, damage to other crops and surrounding plants can be minimized (Fig. 3C). Further by targeting viral RNA for degradation, the engineered host plant can have strong immunity [116]. In the last few years, the CRISPR/Cas9 (clustered regularly interspaced short palindromic repeats /CRISPRassociated 9) genome editing approach has demonstrated a potential to develop virus-resistant plants [117]. CRISPR/ Cas9 can offer an antiviral defense strategy, wherein an RNA-directed nuclease (frequently a Cas protein) slices a viral DNA or RNA at specific target sites complementary to CRISPR RNA, leading to their degradation [118]. Thus, based on modern molecular technologies and targeted gene manipulation via genome editing tools can facilitate future development of broad-spectrum resistance.

To develop proper weed management schemes molecular studies would be essential that can greatly help to explore the interplay of genotype-phenotype. Techniques of restriction fragment length polymorphisms (RFLPs), random amplified polymorphic DNA (RAPD), inter simple sequence repeats (ISSRs), and microsatellites have been applied for weed genomics exploration, which may facilitate the selection of proper biocontrol agents [119]. Additionally, Rowe et al. [120] determined higher genetic variation among populations of Euphorbia esula L. from North America through the genetic diversity assessment using RFLP and RAPD. Similarly, various molecular markers are successfully utilized to understand genetic diversity levels among and within weed species from different geographical regions. However, there is a dearth of such studies on A. conyzoides till now. With RAPD and ISSR markers, Dieu and Ni [121] have evaluated the genetic diversity of 14 different $A$. conyzoides accessions from different places of the Mekong Delta in Vietnam. Eleven primers (3 RAPD and 8 ISSR) amplified a total of 92 fragments (30- RAPD and 62- ISSR). The percentage of polymorphism and polymorphic bands per primer were $59.78 \%$ and $6.11 \pm 2.72$, respectively, indicating a greater genetic diversity among $A$. conyzoides plants from different locations. UPGMA dendrogram separated all the accessions into three discrete groups. Thus, a high degree of genetic diversity might indicate that $A$. conyzoides plants are well adapted to environmental changes [121]; however, more such studies would be necessary to make any meaningful outcome.

Herbicides and pesticides have long been used in crop fields to manage weeds and increase agricultural production [122]. Agricultural intensification and higher production requirements have lead to inefficient utilization of these herbicides and pesticides. Subsequently over time, the majority of the weed species become resistant to these chemicals. Detection of point mutations leading to target-site resistance has provided the potential molecular mechanism(s) for herbicide resistance. Lately, next-generation sequencing (NGS) methods are applied for whole-genome sequencing of mitochondria as well as chloroplast from A. conyzoides [123, 124]. Additionally, genes governing complex non-target-site resistance for herbicide metabolism and translocation have been detected using NGS [14]. The knowledge from weed genomes will facilitate creating solutions for tackling specific weeds. Epigenetic changes, gene copy number variation, and resulting altered gene expression are potential reasons for herbicide tolerance in many weed plants $[125,126]$. Bioinformatics, genetic and genomic studies are essential to understand weed adaptation mechanisms under changing environmental and management conditions. Global food security is facing major trouble due to the yield reduction in several crops although major advancements are being made in breeding, genetics, and other technologies [127]. The major reason behind reduced crop yield is the loss of genetic diversity (genetic erosion) due to the selection of uniform crop varieties with specific traits for a particular environment as they adapt to local conditions [128]. Wild relatives and agricultural weed of crops can provide better resources of genetic diversity that can be utilized for crop improvement [127]. Many weed plants have a strong tolerance against 


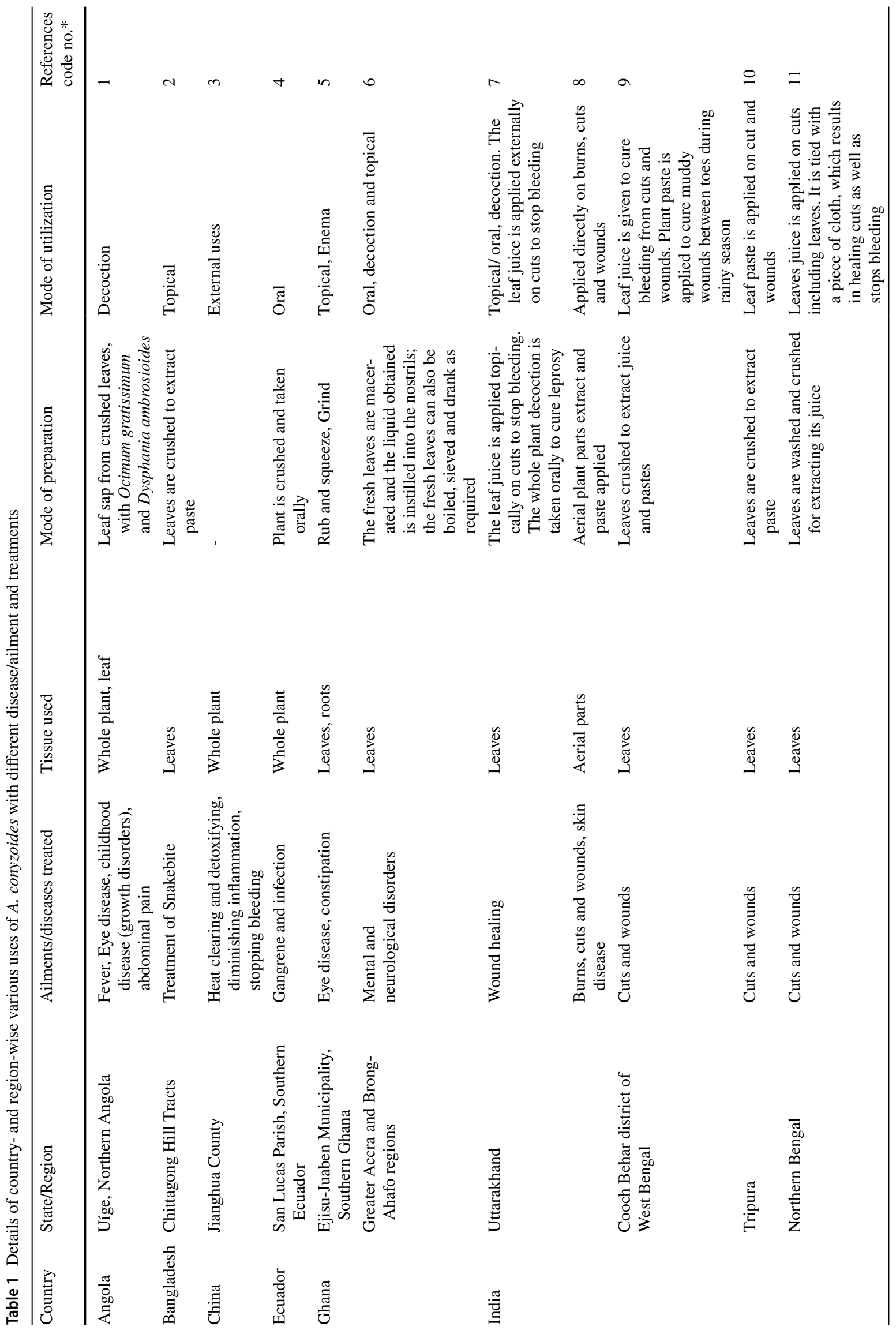




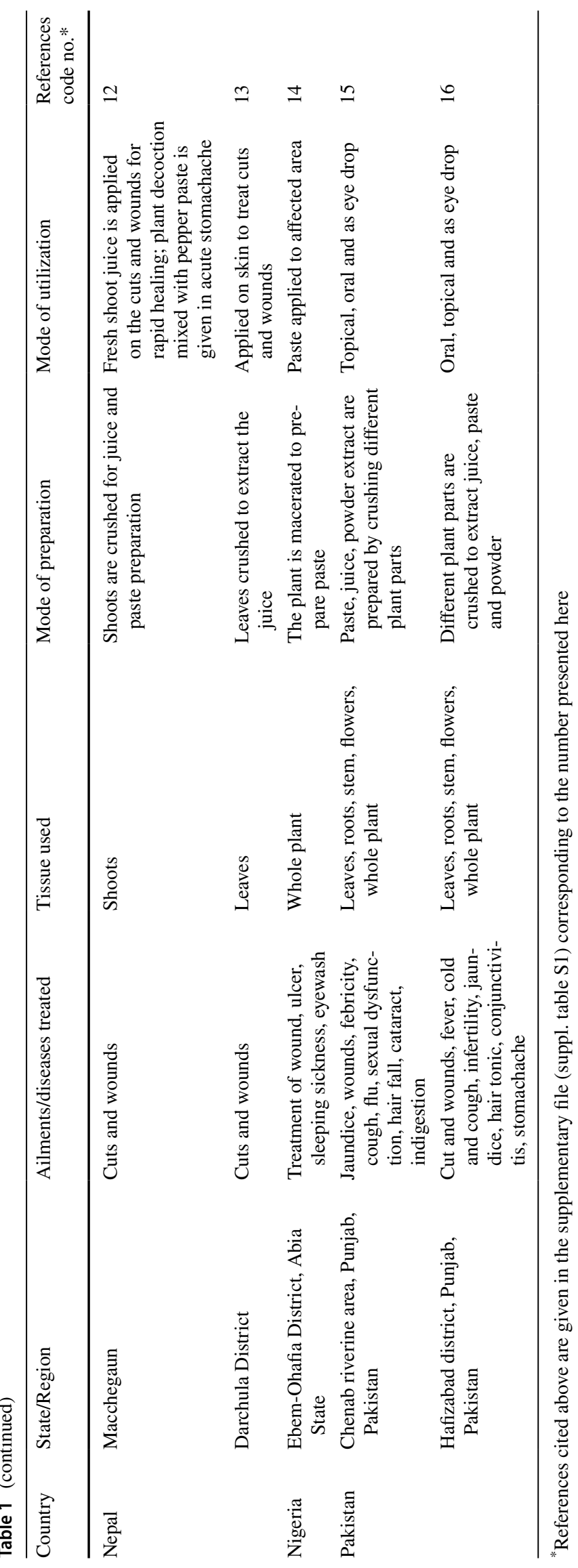




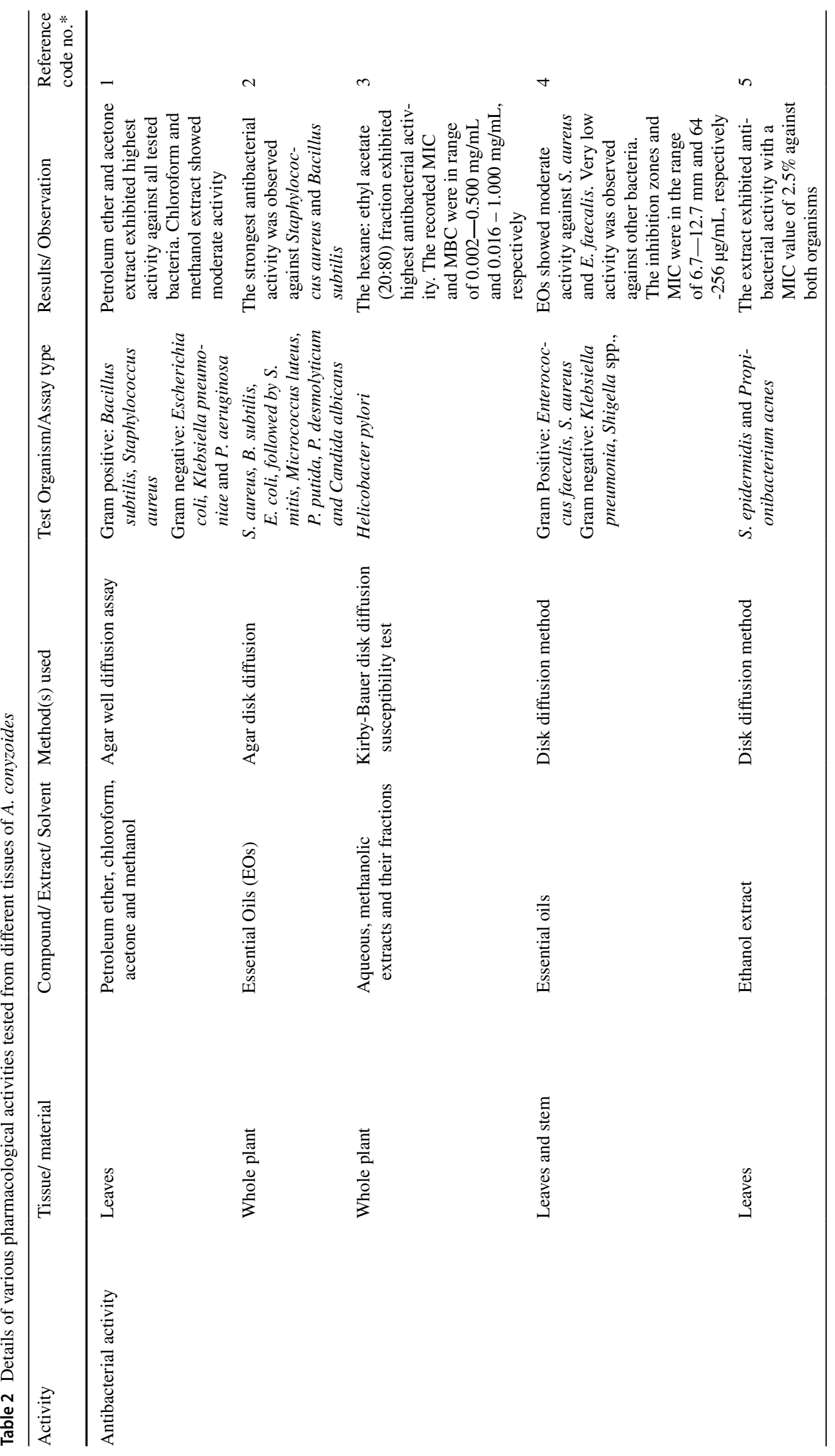




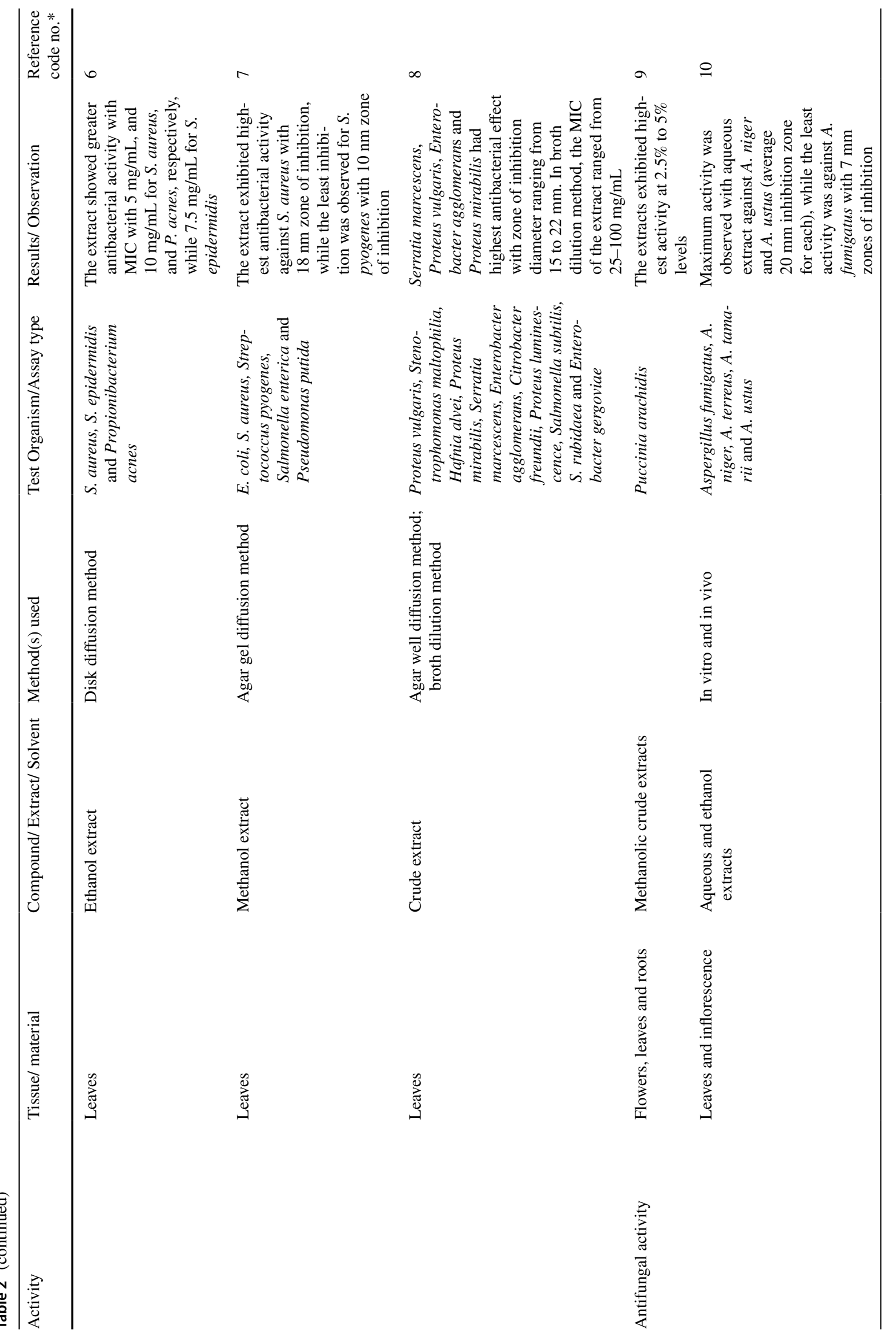




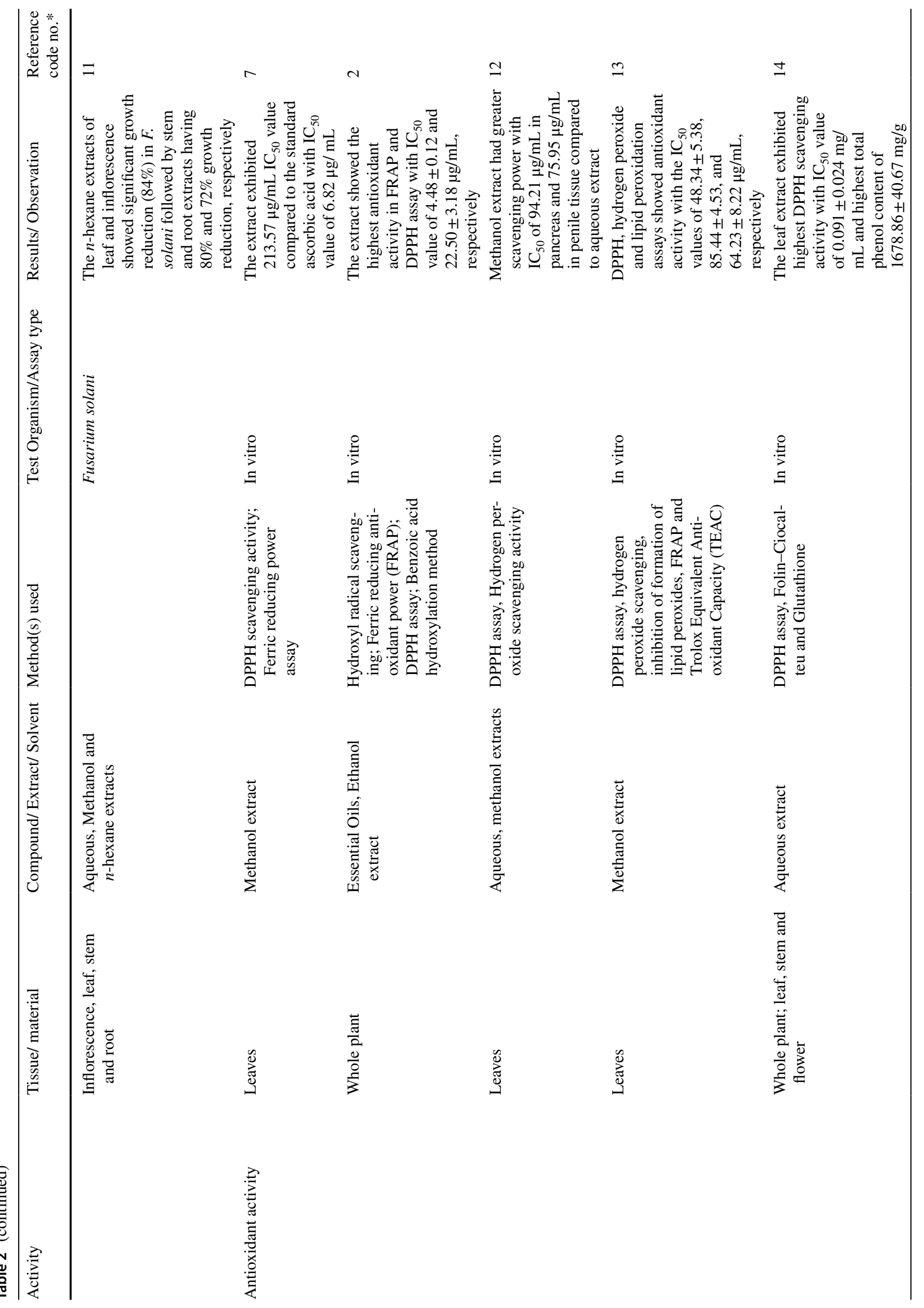




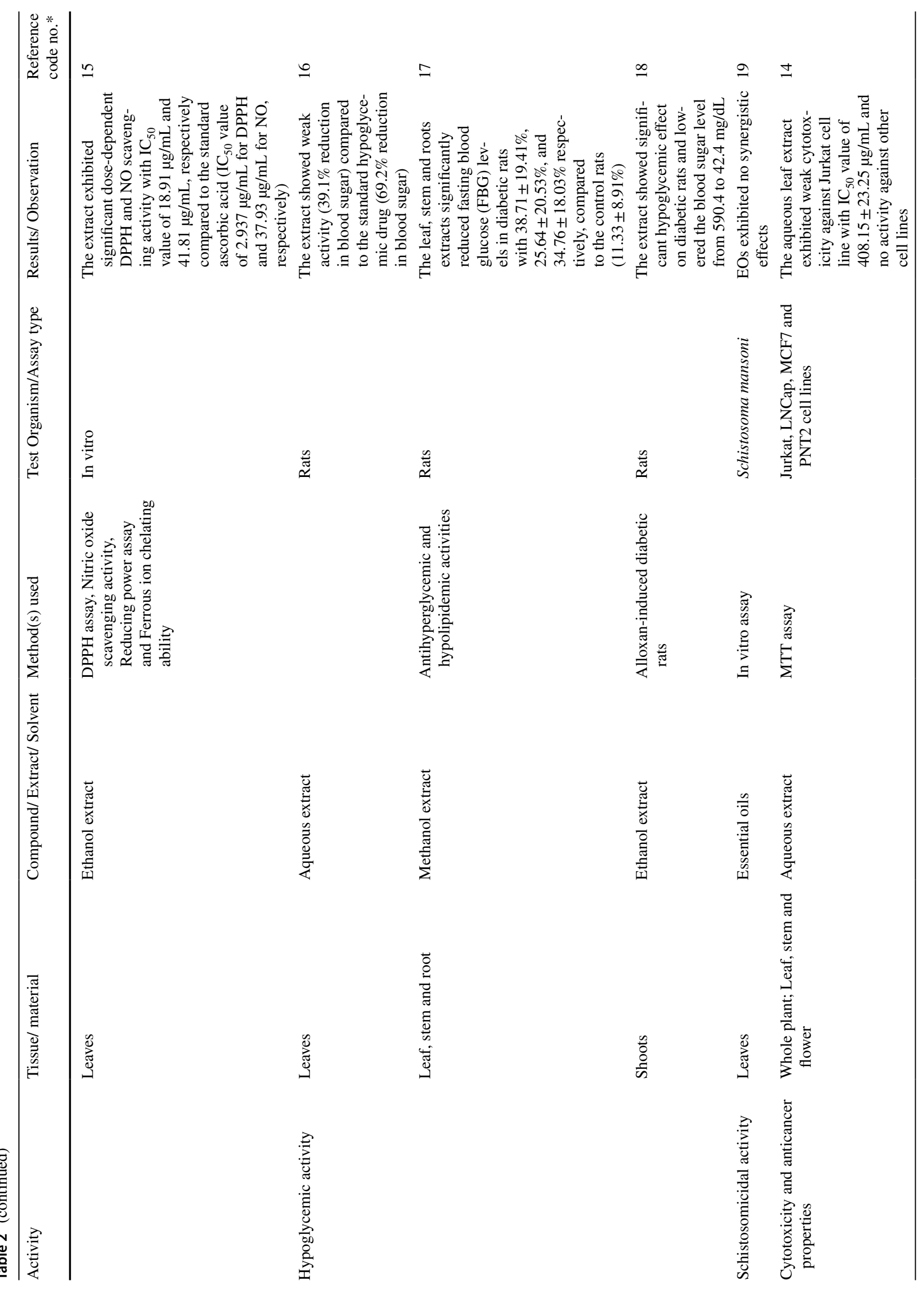




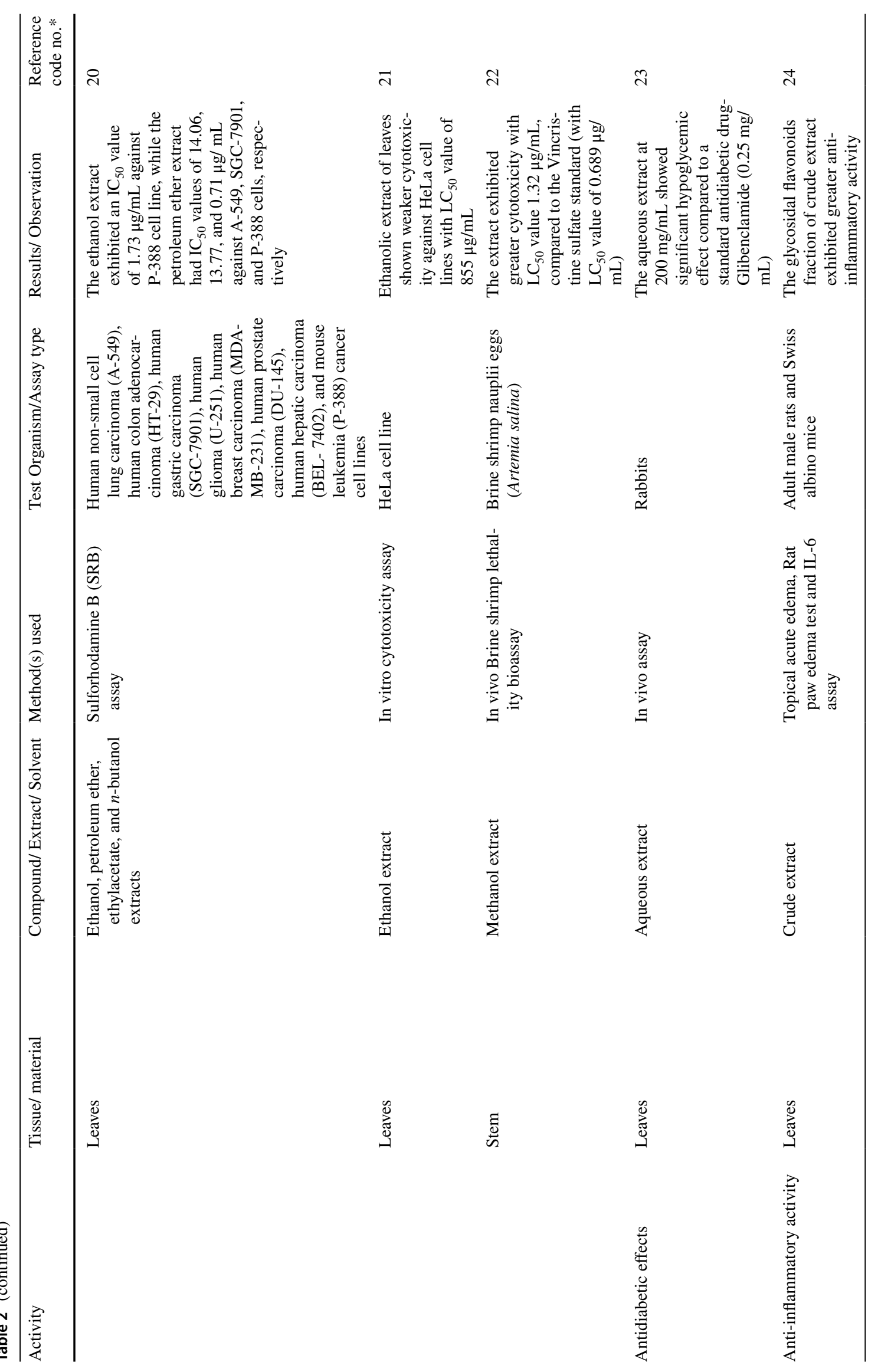




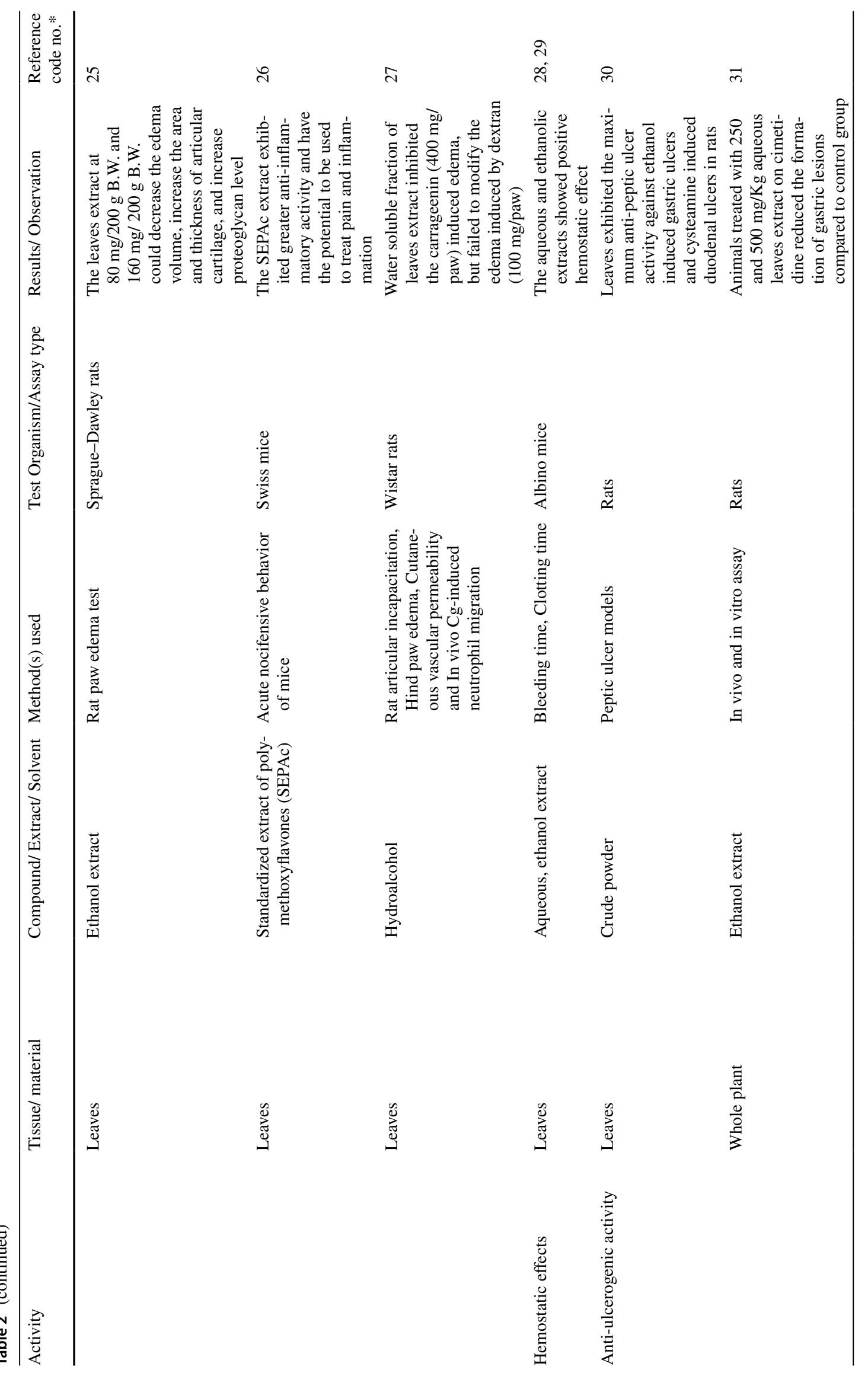




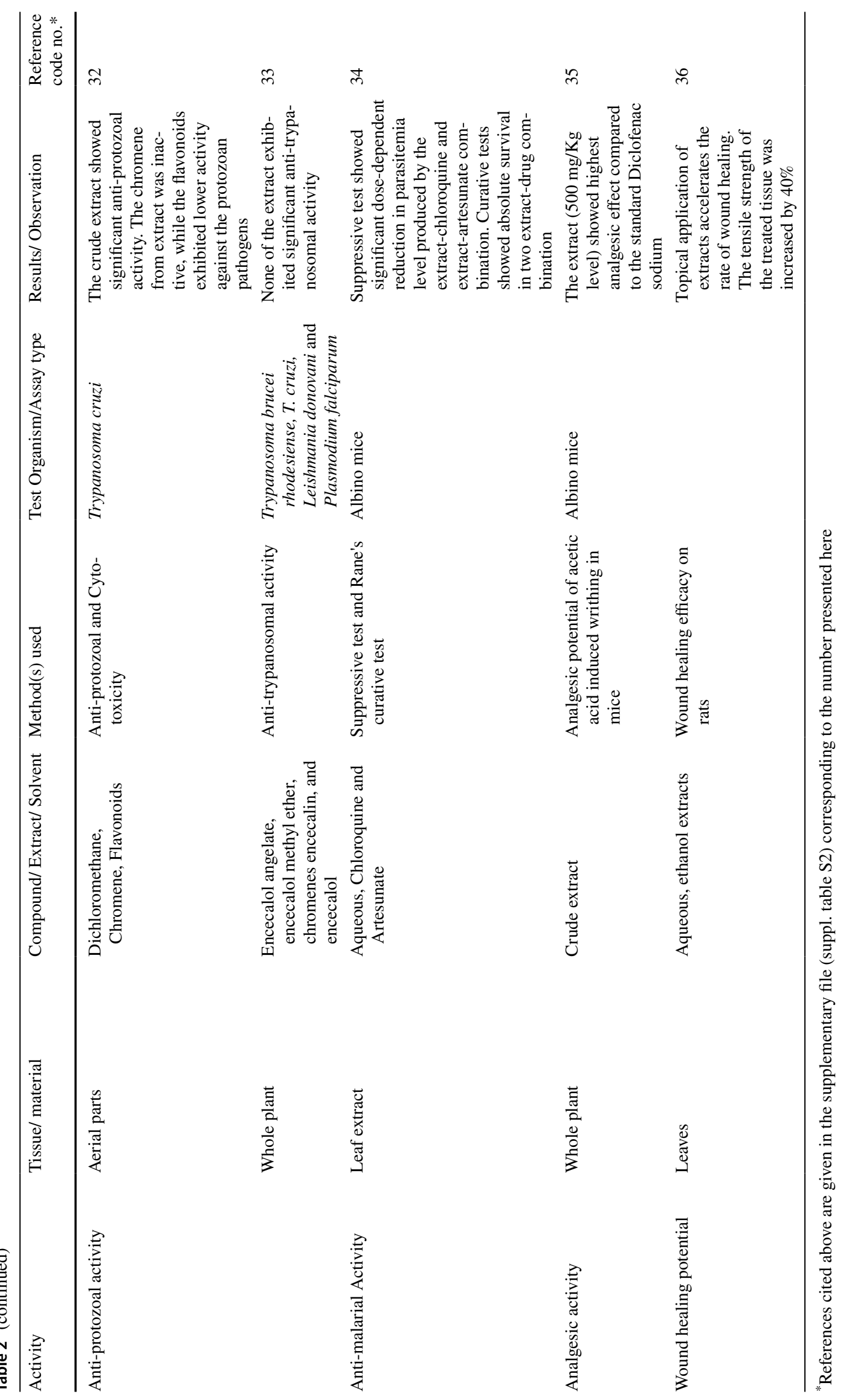


different abiotic stresses [129]. Identification of such target gene(s) from weeds may offer ways to improve abiotic stress tolerance in crops [130]. These genes can be incorporated into new crop varieties utilizing transgenic approaches and multi-omics techniques [14]. Overall, such new lines/ cultivars, thus developed will have improved yield, biomass generation and durable resilience against various biotic and abiotic stresses associated with changing climate and environments [130].

\section{Conclusion}

Although considered invasive, A. conyzoides L. is globally utilized in traditional medicine to treat different ailments and diseases. This is due to the presence of diverse pharmacological properties. However, the mechanistic basis of such activities from this plant has not yet been properly evaluated through various molecular technologies. Also, there is very scanty information on specific adverse side effects of ACE and thus, calls for such independent research efforts for better utilization of this herbal formulation in biopharma. Additionally, it is very rich in sterols, flavonoids, saponins, chromenes, pyrrolizidine, alkaloids, coumarin, pyrrolone, terpenoids, and lignin. As their biosynthetic pathways with gene regulatory components are not properly deciphered till now, future research exploration in such a direction would be widely useful. Besides, in silico analysis/ computational simulations such as molecular docking, and in vitro/ in vivo studies of such compounds may aid to develop various potential drugs against important human diseases. Further, secondary metabolites of $A$. conyzoides have exhibited greater potential against various pathogens and thus, these could be further investigated to generate environment-friendly biopesticide for green agriculture and a safe environment. Similarly, tissue-culture-based protocols may be utilized in mass propagation and for the generation of important specialized metabolites with modern genomics and multi-omics tools. Moreover, A. conyzoides can facilitate the removal of excess nitrogen, phosphorus, and heavy metals from waste or polluted sites. This could be explored further using the nanotechnology-based green synthesis of nanoparticles from plant material that may have various applications not only in agriculture to improve seed germination, growth, and protection of plants to abiotic and biotic stress but also in the removal of heavy metals from polluted areas for a clean environment. The plant is a natural reservoir host of several begomoviruses that transmit the disease to adjacent crop plants. Using advanced molecular technologies, the enhanced knowledge regarding the transfer of the virus from the host to other plants and disease establishment may facilitate the improved defense in crop plants while safeguarding the environment.

Supplementary Information The online version contains supplementary material available at https://doi.org/10.1007/s12033-021-00409-5.

Acknowledgements Authors are thankful to the Heads, Depts. of Botany \& MBB, and other authorities of Tripura University for providing necessary facilities and support.

Author Contributions SP and BBD conceived the idea; BBD prepared the outline and supervised the study; SP and BBD prepared the figures and tables; SP collected necessary information and prepared the first draft; subsequently BBD, BKD \& MBR edited the revised drafts. All authors were involved in finalization of draft and approved the current version of the manuscript.

Funding Not Applicable.

\section{Declarations}

Conflict of interest The authors declare that they have no conflict of interest.

\section{References}

1. Batish, D. R., Kaur, S., Singh, H. P., \& Kohli, R. K. (2009). Role of root-mediated interactions in phytotoxic interference of Ageratum conyzoides with rice (Oryza sativa). Flora-Morphology, Distribution, Functional Ecology of Plants, 204(5), 388-395. https://doi.org/10.1016/j.flora.2008.05.003

2. Kissmann, G., \& Groth, D. (1993). Plantas infestantes e nocivas. Basf Brasileira, Sau Paulo.

3. Dung, N. X., Bien, L. K., Lo, V. N., Leclercq, P. A., Nam, V. V., Trang, N. T. D., \& Phuong, L. V. N. (1996). Recent developments in the study of compositae from Vietnam. Proceedings of the International Compositae Conference, Kew, 655-663.

4. Okunade, A. L. (2002). Ageratum conyzoides L. (Asteraceae). Fitoterapia, 73(1), 1-16. https://doi.org/10.1016/S0367326X(01)00364-1

5. Dogra, K. S., Kohli, R. K., Sood, S. K., \& Dobhal, P. K. (2009). Impact of Ageratum conyzoides L. on the diversity and composition of vegetation in the Shivalik hills of Himachal Pradesh (Northwestern Himalaya), India. International Journal of Biodiversity and Conservation, 1(5), 135-145. https://doi.org/10. 5897/IJBC.9000077

6. Marks, M. K., \& Nwachuku, A. C. (1986). Seed-bank characteristics in a group of tropical weeds. Weed Research, 26(3), 151-158. https://doi.org/10.1111/j.1365-3180.1986.tb00690.x

7. Sood, V. K. (1973). Chemical examination of the flower oil of Ageratum conyzoides L. Flavour Industry, 4(2), 77-78.

8. Kamboj, A., \& Saluja, A. K. (2008). Ageratum conyzoides L.: A review on its phytochemical and pharmacological profile. International Journal of Green Pharmacy (IJGP), 2(2), 59-68. https://doi.org/10.22377/ijgp.v2i2.29

9. Kaur, R., \& Dogra, N. K. (2014). A review on traditional uses chemical constituents and pharmacology of Ageratum conyzoides L (Asteraceae). International Journal of Pharmaceutical \& Biological Archive, 5(5), Article 5. https://www.ijpba.info/ijpba/ index.php/ijpba/article/view/1347 
10. Yadav, N., Ganie, S. A., Singh, B., Chhillar, A. K., \& Yadav, S. S. (2019). Phytochemical constituents and ethnopharmacological properties of Ageratum conyzoides L. Phytotherapy Research, 33(9), 2163-2178. https://doi.org/10.1002/ptr.6405

11. Kohli, R. K., Batish, D. R., Singh, H. P., \& Dogra, K. S. (2006). Status, invasiveness and environmental threats of three tropical American invasive weeds (Parthenium hysterophorus L., Ageratum conyzoides L., Lantana camara L.) in India. Biological Invasions, 8(7), 1501-1510. https://doi.org/10.1007/ s10530-005-5842-1

12. Yuan, X., \& Wen, B. (2018). Seed germination response to high temperature and water stress in three invasive Asteraceae weeds from Xishuangbanna, SW China. PLoS ONE, 13(1), e0191710. https://doi.org/10.1371/journal.pone.0191710

13. Singh, H. P., Batish, D. R., Kohli, R. K., Saxena, D. B., \& Arora, V. (2002). Effect of parthenin-A sesquiterpene lactone from Parthenium hysterophorus-On early growth and physiology of Ageratum conyzoides. Journal of Chemical Ecology, 28(11), 2169-2179. https://doi.org/10.1023/A:1021089013754

14. Ravet, K., Patterson, E. L., Krähmer, H., Hamouzová, K., Fan, L., Jasieniuk, M., Lawton-Rauh, A., Malone, J. M., McElroy, J. S., Merotto, A., Westra, P., Preston, C., Vila-Aiub, M. M., Busi, R., Tranel, P. J., Reinhardt, C., Saski, C., Beffa, R., Neve, P., \& Gaines, T. A. (2018). The power and potential of genomics in weed biology and management. Pest Management Science, 74(10), 2216-2225. https://doi.org/10.1002/ps.5048

15. Huang, Q. Q., Shen, Y. D., Li, X. X., Li, S. L., \& Fan, Z. W. (2016). Invasive Eupatorium catarium and Ageratum conyzoides benefit more than does a common native plant from nutrient addition in both competitive and non-competitive environments. Ecological Research, 31(1), 145-152. https:// doi.org/10.1007/s11284-015-1323-X

16. Huang, Q., Shen, Y., Li, X., Fan, Z., Li, S., \& Liu, Y. (2017). Performance of the invasive Eupatorium catarium and Ageratum conyzoides in comparison with a common native plant under varying levels of light and moisture. Weed Biology and Management, 17(2), 112-121. https://doi.org/10.1111/wbm. 12125

17. Sharma, V., \& Pant, S. (2019). Weed as underutilized bioresource and management tool: A comprehensive review. Waste and Biomass Valorization, 10(7), 1795-1810. https://doi.org/10. 1007/s12649-018-0212-2

18. Xuan, T. D., Anh, L. H., Khang, D. T., Tuyen, P. T., Minh, T. N., Khanh, T. D., \& Trung, K. H. (2016). Weed allelochemicals and possibility for pest management. International Letters of Natural Sciences, 56, 25-39.

19. Anhar, A., Junialdi, R., Zein, A., Advinda, L., \& Leilani, I. (2018). Growth and tomato nutrition content with bandotan (Ageratum Conyzoides L.) bokashi applied. IOP Conference Series: Materials Science and Engineering, 335, 012017. https:// doi.org/10.1088/1757-899X/335/1/012017

20. Luo, Z., Chen, X., Xia, G., \& Chen, X. (2018). Extrinsic environmental factors, not resident diversity itself, lead to invasion of Ageratum conyzoides L. in diverse communities. Ecological Research, 33(6), 1245-1253. https://doi.org/10.1007/ s11284-018-1637-6

21. Zahid, N. Y., Abbasi, N. A., Hafiz, I. A., Hussain, A., \& Ahmad, Z. (2012). Antifungal activity of local fennel (Foeniculum vulgare Mill) extract to growth responses of some soil diseases. African Journal of Microbiology Research, 6(1), 46-51. https:// doi.org/10.5897/AJMR11.794

22. Rajkumar, M., Lee, W. H., \& Lee, K. J. (2005). Screening of bacterial antagonists for biological control of Phytophthora blight of pepper. Journal of Basic Microbiology, 45(1), 55-63. https:// doi.org/10.1002/jobm.200410445
23. Cho, K., Toler, H., Lee, J., Ownley, B., Stutz, J. C., Moore, J. L., \& Augé, R. M. (2006). Mycorrhizal symbiosis and response of sorghum plants to combined drought and salinity stresses. Journal of Plant Physiology, 163(5), 517-528. https://doi.org/ 10.1016/j.jplph.2005.05.003

24. Xuan, T. D., Shinkichi, T., Hong, N. H., Khanh, T. D., \& Min, C. I. (2004). Assessment of phytotoxic action of Ageratum conyzoides L. (billy goat weed) on weeds. Crop Protection, 23(10), 915-922. https://doi.org/10.1016/j.cropro.2004.02.005

25. Kong, C., Hu, F., \& Xu, X. (2002). Allelopathic potential and chemical constituents of volatiles from Ageratum conyzoides under stress. Journal of Chemical Ecology, 28(6), 1173-1182. https://doi.org/10.1023/a:1016229616845

26. Negi, B., Bargali, S. S., Bargali, K., \& Khatri, K. (2020). Allelopathic interference of Ageratum conyzoides L. against rice varieties. Current Agriculture Research, 8(2), 69-76. https://doi.org/ 10.12944/CARJ.8.2.01

27. Gusain, R., \& Suthar, S. (2020). Vermicomposting of invasive weed Ageratum conyzoids: Assessment of nutrient mineralization, enzymatic activities, and microbial properties. Bioresource Technology, 312, 123537. https://doi.org/10.1016/j.biortech. 2020.123537

28. Asthana, V., \& Shukla, A. C. (2014). Water Security in India: Hope, despair, and the challenges of human development. Bloomsbury Academic. https://doi.org/10.5040/9781501302343

29. Varkey, B. K., Dasog, G. S., Wani, S., Sahrawat, K. L., Hebbara, M., \& Patil, C. R. (2015). Impact of long-term application of domestic sewage water on soil properties around Hubli city in Karnataka, India. Agricultural Research, 4(3), 272-276. https:// doi.org/10.1007/s40003-015-0171-9

30. Singh, S., \& Kumar, M. (2006). Heavy metal load of soil, water and vegetables in peri-urban Delhi. Environmental Monitoring and Assessment, 120(1), 79-91. https://doi.org/10.1007/ s10661-005-9050-3

31. Kaur, S., Batish, D. R., \& Kohli, R. K. (2012). Ageratum conyzoides: An alien invasive weed in India. Invasive Alien Plants, 1, 57-76.

32. Kadlec, R. H. (2009). Comparison of free water and horizontal subsurface treatment wetlands. Ecological Engineering, 35(2), 159-174. https://doi.org/10.1016/j.ecoleng.2008.04.008

33. Reddy, K. R., \& De Busk, W. F. (1985). Nutrient removal potential of selected aquatic macrophytes. Journal of Environmental Quality, 14(4), 459-462. https://doi.org/10.2134/jeq1985.00472 $425001400040001 \mathrm{x}$

34. Tanner, C. C. (1996). Plants for constructed wetland treatment systems-A comparison of the growth and nutrient uptake of eight emergent species. Ecological Engineering, 7(1), 59-83. https://doi.org/10.1016/0925-8574(95)00066-6

35. Tilak, A. S., Wani, S. P., Datta, A., Patil, M. D., Kaushal, M., \& Reddy, K. R. (2017). Evaluation of Ageratum conyzoides in field scale constructed wetlands (CWs) for domestic wastewater treatment. Water Science and Technology, 75(10), 2268-2280. https://doi.org/10.2166/wst.2017.119

36. Sharma, V., \& Pant, D. (2018). Biocompatible metal decontamination from soil using Ageratum conyzoides. Environmental Science and Pollution Research, 25(22), 22294-22307. https://doi. org/10.1007/s11356-018-2343-1

37. Macek, T., Macková, M., \& Káš, J. (2000). Exploitation of plants for the removal of organics in environmental remediation. Biotechnology Advances, 18(1), 23-34. https://doi.org/10.1016/ S0734-9750(99)00034-8

38. Trapp, S., \& Karlson, U. (2001). Aspects of phytoremediation of organic pollutants. Journal of Soils and Sediments, 1(1), 37-43. https://doi.org/10.1007/BF02986468

39. Ahmad, A., \& Al-Othman, A. A. S. (2014). Remediation rates and translocation of heavy metals from contaminated soil 
through Parthenium hysterophorus. Chemistry and Ecology, 30(4), 317-327. https://doi.org/10.1080/02757540.2013.871269

40. Abu Bakar, A. J., Ghazali, C. M. R., \& Mat Amin, K. A. (2018). Sodium alginate/Ageratum conyzoides extract film for wound dressing materials. IOP Conference Series: Materials Science and Engineering, 374, 012087. https://doi.org/10.1088/1757899X/374/1/012087

41. Saha, B., Sathyan, A., Mazumder, P., Choudhury, S. P., Kalamdhad, A. S., Khwairakpam, M., \& Mishra, U. (2018). Biochemical methane potential (BMP) test for Ageratum conyzoides to optimize ideal food to microorganism (F/M) ratio. Journal of Environmental Chemical Engineering, 6(4), 5135-5140. https://doi.org/10.1016/j.jece.2018.07.036

42. Bosi, C. F., Rosa, D. W., Grougnet, R., Lemonakis, N., Halabalaki, M., Skaltsounis, A. L., \& Biavatti, M. W. (2013). Pyrrolizidine alkaloids in medicinal tea of Ageratum conyzoides. Revista Brasileira de Farmacognosia, 23(3), 425-432. https:// doi.org/10.1590/S0102-695X2013005000028

43. Faqueti, L. G., Sandjo, L. P., \& Biavatti, M. W. (2017). Simultaneous identification and quantification of polymethoxyflavones, coumarin and phenolic acids in Ageratum conyzoides by UPLC-ESI-QToF-MS and UPLC-PDA. Journal of Pharmaceutical and Biomedical Analysis, 145, 621-628. https://doi. org/10.1016/j.jpba.2017.07.034

44. Tambunan, A. P., Bahtiar, A., \& Tjandrawinata, R. R. (2017). Influence of extraction parameters on the yield, phytochemical, TLC-densitometric quantification of quercetin, and LC-MS profile, and how to standardize different batches for long term from Ageratum conyzoides L. leaves. Pharmacognosy Journal, 9(6), 767-774. https://doi.org/10.5530/pj.2017.6.121

45. González, A. G., Aguiar, Z. E., Grillo, T. A., Luis, J. G., Rivera, A., \& Calle, J. (1991). Chromenes from Ageratum conyzoides. Phytochemistry, 30(4), 1137-1139. https://doi. org/10.1016/S0031-9422(00)95190-2

46. Sarin, R., \& Bansal, N. (2011). Impact of growth regulators on callus production of two medicinal plants viz. Adhatoda vasica and Ageratum conyzoides. International Journal of Research in Plant Science, 1(1), 1-8. https://doi.org/10.13040/IJPSR. 0975-8232.11(1).241-45

47. Nair, A. G. R., Kotiyal, J. P., \& Subramanian, S. S. (1977). Chemical constituents of the leaves of Ageratum conyzoides. Indian Journal of Pharmacy, 39, 108-109.

48. Munikishore, R., Padmaja, A., Gunasekar, D., Blond, A., \& Bodo, B. (2013). Two new flavonoids from Ageratum conyzoides. Indian Journal of Chemistry, 52B, 1479-1482.

49. Gill, S., Mionskowski, H., Janczewska, D., \& Kapsa, G. (1978). Flavonoid compounds of the Ageratum conyzoides L. herb. Acta Poloniae Pharmaceutica, 35(2), 241-243.

50. Ramachadran, A. G., Kotiyal, J. P., \& Subramanian, S. S. (1977). Chemical constituents of the leaves of Ageratum conyzoides L. Indian Journal of Pharmacy, 39, 108-109.

51. Awad, N. E., Kassem, H. A., Elkhayat, Z. A., \& El-feky, A. M. (2013). Chemical composition and anti-inflammatory evaluation of Ageratum conyzoides L. leaves. Journal of Applied Sciences Research, 9(3), 2126-2134.

52. Menut, C., Lamaty, G., Zollo, P. H. A., Kuiate, J. R., \& Bessière, J. M. (1993). Aromatic plants of tropical central Africa. Part X Chemical composition of the essential oils of Ageratum houstonianum Mill. And Ageratum conyzoides L. from Cameroon. Flavour and Fragrance Journal, 8(1), 1-4. https://doi.org/10.1002/ffj.2730080102

53. Usman, L. A., Zubair, M. F., Olawore, N. O., Muhammad, N. O., M'civer, F. A., \& Ismaeel, R. O. (2013). Chemical constituents of flower essential oil of Ageratum conyzoides growing in Nigeria. Elixir Organic Chemistry, 54, 12463-12465.
54. Kouame, B. K. F. P., Toure, D., Kablan, L., Bedi, G., Tea, I., Robins, R., Chalchat, J. C., \& Tonzibo, F. (2018). Chemical constituents and antibacterial activity of essential oils from flowers and stems of Ageratum conyzoides from Ivory Coast. Records of Natural Products, 12(2), 160-168. https://doi.org/ 10.25135/rnp.22.17.06.040

55. Ekundayo, O., Laakso, I., \& Hiltunen, R. (1988). Essential oil of Ageratum conyzoides. Planta Medica, 54(1), 55-57. https:// doi.org/10.1055/s-2006-962336

56. Adebayo, A. H., Tan, N. H., Akindahunsi, A. A., Zeng, G. Z., \& Zhang, Y. M. (2010). Anticancer and antiradical scavenging activity of Ageratum conyzoides L. (Asteraceae). Pharmacognosy Magazine, 6(21), 62-66. https://doi.org/10.4103/09731296.59968

57. Wuyep, P. A., Musa, H. D., Ezemokwe, G. C., Nyam, D. D., \& SilaGyang, M. D. (2017). Phytochemicals from Ageratum conyzoides $\mathrm{L}$. extracts and their antifungal activity against virulent Aspergillus spp. Journal of Academia and Industrial Research, 6(3), 32-39.

58. Yusnawan, E., \& Inayati, A. (2018). Antifungal activity of crude extracts of Ageratum conyzoides, Cyperus rotundus, and Amaranthus spinosus against rust disease. AGRIVITA, Journal of Agricultural Science, 40(3), 403-414. https://doi.org/10.17503/ agrivita.v40i0.1889

59. Kong, C., Liang, W., Hu, F., Xu, X., Wang, P., Jiang, Y., \& Xing, B. (2004). Allelochemicals and their transformations in the Ageratum conyzoides intercropped citrus orchard soils. Plant and Soil, 264(1), 149-157. https://doi.org/10.1023/B:PLSO.00000 47759.65133.fa

60. Javed, S., \& Bashir, U. (2012). Antifungal activity of different extracts of Ageratum conyzoides for the management of Fusarium solani. African Journal of Biotechnology, 11(49), 11022-11029. https://doi.org/10.4314/ajb.v11i49

61. Jaya, S. P., Prakash, B., \& Dubey, N. K. (2014). Insecticidal activity of Ageratum conyzoides L., Coleus aromaticus Benth. And Hyptis suaveolens (L.) Poit essential oils as fumigant against storage grain insect Tribolium castaneum Herbst. Journal of Food Science and Technology, 51(9), 2210-2215. https://doi. org/10.1007/s13197-012-0698-8

62. Saxena, R., \& Sharma, A. K. (2005). Insecticidal potentialities of Ageratum conyzoides and Nerium indicum leaves extracts against Epilachna 28-punctata (F.). Vegetos-An International Journal of Plant Research, 18(1 \& 2), 43-45.

63. Prasetio, D. (2018). Application of biopesticides from Ageratum conyzoides to reduce use of chemical pesticide in Caisim (Brassica juncea). In The 3rd International Conference of Integrated Intellectual Community. Retrieved from https://www.ssrn.com/.

64. Yuliani, \& Rahayu, Y. S. (2021). The Potency of Ageratum conyzoides as Biopesticide. Advances in Biological Sciences Research, volume 11, Proceedings of the Joint Symposium on Tropical Studies (JSTS-19).

65. Banaras, S., Javaid, A., \& Khan, I. H. (2020). Bioassays guided fractionation of Ageratum conyzoides extract for the identification of natural antifungal compounds against Macrophomina phaseolina. International Journal of Agriculture \& Biology, 25, 761-767. https://doi.org/10.17957/IJAB/15.1727

66. Rioba, N. B., \& Stevenson, P. C. (2017). Ageratum conyzoides L. for the management of pests and diseases by small holder farmers. Industrial Crops and Products, 110, 22-29. https://doi.org/ 10.1016/j.indcrop.2017.06.068

67. Natarajan, A., Elavazhagan, P., \& Prabhakaran, J. (2014). Allelopathic potential of billy goat weed Ageratum conyzoides $\mathrm{L}$. and Cleome viscosa L. on germination and growth of Sesamum indicum L. International Journal of Current Biotechnology, 2(2), $21-24$. 
68. Kato-Noguchi, H. (2001). Assessment of the allelopathic potential of Ageratum conyzoides. Biologia Plantarum, 44(2), 309311. https://doi.org/10.1023/A:1010228232355

69. Sharma, V., \& Sarkar, I. N. (2013). Bioinformatics opportunities for identification and study of medicinal plants. Briefings in Bioinformatics, 14(2), 238-250. https://doi.org/10.1093/bib/bbs021

70. Clarkson, C., Maharaj, V. J., Crouch, N. R., Grace, O. M., Pillay, P., Matsabisa, M. G., Bhagwandin, N., Smith, P. J., \& Folb, P. I. (2004). In vitro antiplasmodial activity of medicinal plants native to or naturalized in South Africa. Journal of Ethnopharmacology, 92(2-3), 177-191. https://doi.org/10.1016/j.jep.2004.02.011

71. Thatoi, H., \& Patra, J. K. (2011). Biotechnology and pharmacological evaluation of medicinal plants: An overview. Journal of Herbs, Spices \& Medicinal Plants, 17(3), 214-248. https://doi. org/10.1080/10496475.2011.602471

72. Kokwaro, J. O. (1976). Medicinal plants of East Africa. East African Literature Bureau. http://erepository.uonbi.ac.ke/handle/ $11295 / 34820$

73. Adjanohoun, E. J., Ahyi, A. M. R., Ake Assi, L., Moutsambote, J. M., Mpati, J., Doulou, V., \& Baniakina, J. (1988). Medecine traditionnelle et pharmacopee: Contribution aux etudes ethnobotaniques et floristiques en Republique Populaire du Congo. Paris (France) Agence de Cooperation Culturelle et Technique.

74. Detering, M., Steels, E., Koyyalamudi, S. R., Allifranchini, E., Bocchietto, E., \& Vitetta, L. (2017). Ageratum conyzoides L. inhibits 5-alpha-reductase gene expression in human prostate cells and reduces symptoms of benign prostatic hypertrophy in otherwise healthy men in a double blind randomized placebo controlled clinical study. BioFactors, 43(6), 789-800. https://doi. org/10.1002/biof.1389

75. Oso, B. J., \& Olaoye, I. F. (2020). Comparative in vitro studies of antiglycemic potentials and molecular docking of Ageratum conyzoides $\mathrm{L}$. and Phyllanthus amarus L. methanolic extracts. SN Applied Sciences, 2, 629. https://doi.org/10.1007/ s42452-020-2275-5

76. Kotta, J. C., Lestari, A. B. S., Candrasari, D. S., \& Maywan Hariono, M. (2020). Medicinal effect, in silico bioactivity prediction, and pharmaceutical formulation of Ageratum conyzoides L.: A review. Scientifica. https://doi.org/10.1155/2020/6420909

77. Thuy, B. T. P., Hieu, L. T., My, T. T. A., Hai, N. T. T., Loan, H. T. P., Thuy, N. T. T., Triet, N. T., Anh, T. T. V., Dieu, N. T. X., Quy, P. T., Trung, N. V., Quang, D. T., Huynh, L. K., \& Nhung, N. T. A. (2021). Screening for Streptococcus pyogenes antibacterial and Candida albicans antifungal bioactivities of organic compounds in natural essential oils of Piper betle L., Cleistocalyx operculatus L. and Ageratum conyzoides L. Chemicals Papers, 75, 1507-1519. https://doi.org/10.1007/s11696-020-01404-x

78. Hariono, M., Rollando, R., Yoga, I., Harjono, A., Suryodanindro, A., Yanuar, M., Gonzaga, T., Parabang, Z., Hariyono, P., Febriansah, R., Hermawansyah, A., Setyani, W., \& Wahab, H. (2021). Bioguided fractionation of local plants against matrix metalloproteinase 9 and its cytotoxicity against breast cancer cell models: In silico and in vitro study (Part II). Molecules, 26(5), 1464. https://doi.org/10.3390/molecules26051464

79. Ashley, N. T., Weil, Z. M., \& Nelson, R. J. (2012). Inflammation: Mechanisms, costs, and natural variation. Annual Review of Ecology, Evolution, and Systematics, 43(1), 385-406. https:// doi.org/10.1146/annurev-ecolsys-040212-092530

80. Vigil de Mello, S. V. G., da Rosa, J. S., Facchin, B. M., Luz, A. B. G., Vicente, G., Faqueti, L. G., Rosa, D. W., Biavatti, M. W., \& Fröde, T. S. (2016). Beneficial effect of Ageratum conyzoides Linn (Asteraceae) upon inflammatory response induced by carrageenan into the mice pleural cavity. Journal of Ethnopharmacology, 194, 337-347. https://doi.org/10.1016/j.jep.2016.09.003

81. van Walsem, A., Pandhi, S., Nixon, R. M., Guyot, P., Karabis, A., \& Moore, R. A. (2015). Relative benefit-risk comparing diclofenac to other traditional non-steroidal anti-inflammatory drugs and cyclooxygenase- 2 inhibitors in patients with osteoarthritis or rheumatoid arthritis: A network meta-analysis. Arthritis Research \& Therapy, 17, 66. https://doi.org/10.1186/ s13075-015-0554-0

82. Bahtiar, A., Nurazizah, M., Roselina, T., Tambunan, A. P., \& Arsianti, A. (2017). Ethanolic extracts of babandotan leaves (Ageratum conyzoides L.) prevents inflammation and proteoglycan degradation by inhibiting TNF- $\alpha$ and MMP-9 on osteoarthritis rats induced by monosodium iodoacetate. Asian Pacific Journal of Tropical Medicine, 10(3), 270-277. https:// doi.org/10.1016/j.apjtm.2017.03.006

83. Adam, S. E. I., Al-Yahya, M. A., \& Al-Farhan, A. H. (2001). Response of Najdi sheep to oral administration of Citrullus colocynthis fruits, Nerium oleander leaves or their mixture. Small Ruminant Research: The Journal of the International Goat Association, 40(3), 239-244. https://doi.org/10.1016/ s0921-4488(01)00184-5

84. Padmapriya, H., Karthikeyan, A. V. P., Hussain, J. G., Karthi, C., \& Velayutham, P. (2011). An efficient protocol for in vitro propagation of Solanum nigrum L. from nodal explants. Journal of Agricultural Technology, 7(4), 1063-1073.

85. Nielsen, E., Temporiti, M. E. E., \& Cella, R. (2019). Improvement of phytochemical production by plant cells and organ culture and by genetic engineering. Plant Cell Reports, 38(10), 1199-1215. https://doi.org/10.1007/s00299-019-02415-z

86. Caleja, C., Ribeiro, A., Barreiro, M. F., \& Ferreira, I. C. F. R. (2017). Phenolic compounds as nutraceuticals or functional food ingredients. Current Pharmaceutical Design, 23(19), 2787-2806. https://doi.org/10.2174/13816128226661612271 53906

87. Pandey, M., Jayaramaiah, R. H., Dholakia, B. B., Punekar, S. A., \& Giri, A. P. (2017). A viable alternative in vitro system and comparative metabolite profiling of different tissues for the conservation of Ceropegia karulensis. Plant Cell Tissue Organ Culture, 131, 391-405. https://doi.org/10.1007/s11240-017-1292-6

88. Tripathi, M. K., Mishra, N., Tiwari, S., Shyam, C., Singh, S., \& Ahuja, A. (2019). Plant tissue culture technology: Sustainable option for mining high value pharmaceutical compounds. International Journal of Current Microbiology and Applied Sciences, 8(02), 1002-1010. https://doi.org/10.20546/ijcmas.2019.802.116

89. Pandey, M., Dholakia, B. B., Jayaramaiah, R. H., Punekar, S. A., \& Giri, A. P. (2020). Combinatorial approach through in vitro regeneration and phytochemical profiling of Ceropegia media (Huber) Ans.: A potential way forward in the conservation of an endangered medicinal plant from the Western Ghats in India. Journal of Plant Growth Regulation. https://doi.org/10.1007/ s00344-020-10173-6

90. Sivanandhan, G., Mariashibu, T. S., Arun, M., Rajesh, M., Kasthurirengan, S., Selvaraj, N., \& Ganapathi, A. (2011). The effect of polyamines on the efficiency of multiplication and rooting of Withania somnifera (L.) Dunal and content of some withanolides in obtained plants. Acta Physiologiae Plantarum, 33(6), 2279. https://doi.org/10.1007/s11738-011-0768-y

91. Sharma, L. (2008). Micropropagation of Ageratum conyzoides L.-An important medicinal plant. Journal of Phytological Research, 21(1), 47-52.

92. Renu, S., \& Nidhi, B. (2011). Phytosterols from in vivo and in vitro cultures of two medicinal plants viz. Adatoda vasica and Ageratum conyzoides. International Journal of Research in Ayurveda and Pharmacy (IJRAP), 2(3), 927-930.

93. Rethinam, R., \& Jeyachandran, R. (2017). Micropropagation from Ageratum conyzoides L. Indo American Journal of Pharmaceutical Research, 7(08), 674-680.

94. Fitriani, A., Ihsan, F., \& Hamdiyati, Y. (2015). Antibacterial activity of Shewanella and Pseudomonas as endophytic 
bacteria from the root of Ageratum conyzoides L. Asian Journal of Applied Sciences, 3, 415-420.

95. Momin, M. D., \& Ibrahim, K. S. (2021). Endophytic bacteria isolated from Ageratum conyzoides L. and Mikania micrantha Kunth of Mizoram, Northeast India. National Academy Science Letters, 44, 355-358. https://doi.org/10.1007/s40009-020-01013-y

96. Ujam, N. T., Eze, P. M., Chukwunwejim, C. R., Okoye, F. B. C., \& Esimone, C. O. (2019). Antimicrobial and immunomodulatory activities of secondary metabolites of an endophytic fungus isolated from Ageratum conyzoides. Current Life Sciences, 5(1), 19-27. https://doi.org/10.5281/zenodo.3240604

97. Qiao, Z., Wang, Q., Liu, J., \& Wang, M. (2021). Antioxidant and antibacterial activities of the ethyl acetate extracts of endophytic fungi isolated from Ageratum conyzoides L. Journal of Chinese Pharmaceutical Sciences, 30(5), 421-433. https://doi.org/10. 5246/jcps.2021.05.033

98. Moffat, A. S. (1999). Gemini viruses emerge as serious crop threat. Science, 286(5446), 1835-1835. https://doi.org/10.1126/ science.286.5446.1835

99. Huang, J. F., \& Zhou, X. P. (2006). Molecular characterization of two distinct begomoviruses from Ageratum conyzoides and Malvastrum coromandelianum in China. Journal of Phytopathology, 154(11-12), 648-653. https://doi.org/10.1111/j.1439-0434. 2006.01162.x

100. Kumar, Y., Hallan, V., \& Zaidi, A. A. (2011). First report of Ageratum enation virus infecting Crassocephalum crepidioides (Benth.) S. Moore and Ageratum conyzoides L. in India. Journal of General Plant Pathology, 77(3), 214-216. https://doi.org/10. 1007/s10327-011-0308-z

101. Srivastava, A., Agrawal, L., Raj, R., Jaidi, M., Raj, S. K., Gupta, S., Dixit, R., Singh, P. C., Tripathi, T., Sidhu, O. P., Singh, B. N., Shukla, S., Chauhan, P. S., \& Kumar, S. (2017). Ageratum enation virus infection induces programmed cell death and alters metabolite biosynthesis in Papaver somniferum. Frontiers in Plant Science. https://doi.org/10.3389/fpls.2017.01172

102. Hanley-Bowdoin, L., Bejarano, E. R., Robertson, D., \& Mansoor, S. (2013). Gemini viruses: Masters at redirecting and reprogramming plant processes. Nature Reviews Microbiology, 11(11), 777-788. https://doi.org/10.1038/nrmicro3117

103. Wyant, P. S., Strohmeier, S., Schäfer, B., Krenz, B., Assunção, I. P., de Lima, G. S. A., \& Jeske, H. (2012). Circular DNA genomics (circomics) exemplified for gemini viruses in bean crops and weeds of North-eastern Brazil. Virology, 427(2), 151-157. https://doi.org/10.1016/j.virol.2012.02.007

104. Paprotka, T., Metzler, V., \& Jeske, H. (2010). The first DNA 1-like $\alpha$ satellite in association with new world begomoviruses in natural infections. Virology, 404(2), 148-157. https://doi.org/ 10.1016/j.virol.2010.05.003

105. Kubicek, C. P., Starr, T. L., \& Glass, N. L. (2014). Plant cell wall-degrading enzymes and their secretion in plant-pathogenic fungi. Annual Review of Phytopathology, 52, 427-451. https:// doi.org/10.1146/annurev-phyto-102313-045831

106. Wang, M.-B., Masuta, C., Smith, N. A., \& Shimura, H. (2012). RNA silencing and plant viral diseases. Molecular PlantMicrobe Interactions, 25(10), 1275-1285. https://doi.org/10. 1094/MPMI-04-12-0093-CR

107. Castillo-Urquiza, G. P., Beserra, J. E. A., Bruckner, F. P., Lima, A. T. M., Varsani, A., Alfenas-Zerbini, P., \& Murilo Zerbini, F. (2008). Six novel begomoviruses infecting tomato and associated weeds in Southeastern Brazil. Archives of Virology, 153(10), 1985-1989. https://doi.org/10.1007/s00705-008-0172-0

108. Saeed, S. T., \& Samad, A. (2017). Emerging threats of begomoviruses to the cultivation of medicinal and aromatic crops and their management strategies. Virus Disease, 28(1), 1-17. https:// doi.org/10.1007/s13337-016-0358-0
109. Ashfaq, M., Hebert, P. D. N., Mirza, M. S., Khan, A. M., Mansoor, S., Shah, G. S., \& Zafar, Y. (2014). DNA barcoding of Bemisia tabaci complex (Hemiptera: Aleyrodidae) reveals Southerly expansion of the dominant whitefly species on cotton in Pakistan. PLoS ONE, 9(8), e104485. https://doi.org/10.1371/ journal.pone.0104485

110. Islam, W., Zhang, J., Adnan, M., Noman, A., Zaynab, M., \& Wu, Z. (2017). Plant virus ecology: A glimpse of recent accomplishments. Applied Ecology and Environmental Research, 15(1), 691-705. https://doi.org/10.15666/aeer/1501_691705

111. Gilbertson, R. L., Batuman, O., Webster, C. G., \& Adkins, S. (2015). Role of the insect supervectors Bemisia tabaci and Frankliniella occidentalis in the emergence and global spread of plant viruses. Annual Review of Virology, 2(1), 67-93. https:// doi.org/10.1146/annurev-virology-031413-085410

112. Adnan, M., Zheng, W., Islam, W., Arif, M., Abubakar, Y. S., Wang, Z., \& Lu, G. (2018). Carbon catabolite repression in filamentous fungi. International Journal of Molecular Sciences, 19(1), 48. https://doi.org/10.3390/ijms19010048

113. Fahmy, I. F., \& Abou-Ali, R. M. (2015). Studying genetic diversity of whitefly B. tabaci Egyptian isolates in relation to some worldwide isolates. Journal of Genetic Engineering \& Biotechnology, 13(1), 87-92. https://doi.org/10.1016/j.jgeb.2014.12.004

114. Andou, T., Yamaguchi, A., Kawano, S., Kawabe, K., Ueda, S., \& Onuki, M. (2010). Ageratum yellow vein virus isolated from tomato plants with leaf curl on Ishigaki Island, Okinawa, Japan. Journal of General Plant Pathology, 76(4), 287-291. https://doi. org/10.1007/s10327-010-0239-0

115. Osusky, M., Zhou, G., Osuska, L., Hancock, R. E., Kay, W. W., \& Misra, S. (2000). Transgenic plants expressing cationic peptide chimeras exhibit broad-spectrum resistance to phytopathogens. Nature Biotechnology, 18(11), 1162-1166. https://doi.org/10. $1038 / 81145$

116. Rosa, C., Kuo, Y. W., Wuriyanghan, H., \& Falk, B. W. (2018). RNA interference mechanisms and applications in plant pathology. Annual Review of Phytopathology, 56, 581-610. https://doi. org/10.1146/annurev-phyto-080417-050044

117. Wright, A. V., Nuñez, J. K., \& Doudna, J. A. (2016). Biology and applications of CRISPR systems: Harnessing nature's toolbox for genome engineering. Cell, 164(1-2), 29-44. https://doi.org/10. 1016/j.cell.2015.12.035

118. Wu, W. Y., Lebbink, J. H. G., Kanaar, R., Geijsen, N., \& van der Oost, J. (2018). Genome editing by natural and engineered CRISPR-associated nucleases. Nature Chemical Biology, 14(7), 642-651. https://doi.org/10.1038/s41589-018-0080-x

119. Horvath, D. (2010). Genomics for weed science. Current Genomics, 11(1), 47-51. https://doi.org/10.2174/138920210790217972

120. Rowe, M. L., Lee, D. J., Nissen, S. J., Bowditch, B. M., \& Masters, R. A. (1997). Genetic variation in North American leafy spurge (Euphorbia esula) determined by DNA markers. Weed Science, 45(3), 446-454. https://doi.org/10.1017/S004317450 0093140

121. Diệu H. K., \& Ni N. T. H. (2017). The genetic diversity and the antibacterial activity of Ageratum conyzoides Linn. Tap chí Khoa học Trường Đại học Cần Tho, Số 07, 45-50. https://doi.org/10. 22144/ctu.jen.2017.048

122. Johnson, W. G., Davis, V. M., Kruger, G. R., \& Weller, S. C. (2009). Influence of glyphosate-resistant cropping systems on weed species shifts and glyphosate-resistant weed populations. European Journal of Agronomy, 31(3), 162-172. https://doi.org/ 10.1016/j.eja.2009.03.008

123. Luo, Z., \& Pan, L. (2019). Characterization of the complete mitochondrial genome of Ageratum conyzoides. Mitochondrial DNA Part B, 4(2), 3540-3541. https://doi.org/10.1080/23802359. 2019.1676176 
124. Qiao, Z., Chen, Z., \& Wang, Q. (2019). The complete chloroplast genome of Ageratum conyzoides (Asteraceae). Mitochondrial DNA Part B, 4(2), 3342-3343. https://doi.org/10.1080/23802 359.2019.1673241

125. Laforest, M., Soufiane, B., Simard, M.-J., Obeid, K., Page, E., \& Nurse, R. E. (2017). Acetyl-CoA carboxylase overexpression in herbicide-resistant large crabgrass (Digitaria sanguinalis). Pest Management Science, 73(11), 2227-2235. https://doi.org/10. 1002/ps.4675

126. Patterson, E. L., Pettinga, D. J., Ravet, K., Neve, P., \& Gaines, T. A. (2018). Glyphosate resistance and EPSPS gene duplication: Convergent evolution in multiple plant species. The Journal of Heredity, 109(2), 117-125. https://doi.org/10.1093/jhered/ esx087

127. Mickelbart, M. V., Hasegawa, P. M., \& Bailey-Serres, J. (2015). Genetic mechanisms of abiotic stress tolerance that translate to crop yield stability. Nature Reviews Genetics, 16(4), 237-251. https://doi.org/10.1038/nrg3901
128. van de Wouw, M., Kik, C., van Hintum, T., van Treuren, R., \& Visser, B. (2010). Genetic erosion in crops: Concept, research results and challenges. Plant Genetic Resources, 8(1), 1-15. https://doi.org/10.1017/S1479262109990062

129. Kuester, A., Conner, J. K., Culley, T., \& Baucom, R. S. (2014). How weeds emerge: A taxonomic and trait-based examination using United States data. New Phytologist, 202(3), 1055-1068. https://doi.org/10.1111/nph.12698

130. Basu, C., \& Zwenger, S. R. (2009). An introduction to molecular genetic and genomic techniques. In Weedy and invasive plant genomics (pp. 11-24). Wiley. https://doi.org/10.1002/97808 13806198.ch2

Publisher's Note Springer Nature remains neutral with regard to jurisdictional claims in published maps and institutional affiliations. 